\title{
WEST GERMANY'S "BROWNLOW COMMITTEE": THE FIRST REPORT*
}

\author{
HANS BAADE**
}

\section{INTRODUCTION}

The present Federal Government of West Germany, which took office on October 22, 1969 , is committed to a program of internal reforms, including the improvement of policy planning. The new emphasis on government efficiency is already evidenced by three distinct innovations in Chancellor Brandt's cabinet: the reduction in the number of ministries from I9 to I5; the elevation of the Chancellor's Office to Ministry status; and the establishment of positions of Parliamentary Secretary in all ministries.

These innovations were greatly facilitated, and perhaps even made possible on such short notice, by the work of the Project Group for Government and Administrative Reform, which was established less than a year earlier by a Cabinet Committee of seven, headed by Chancellor Kiesinger. The Project Group submitted its first report on August 3x, $x 969$-too late for consideration before the elections of September 28, and, indeed, so close to them that it was treated as confidential until the votes were in. ${ }^{2}$ The report was released early in October, I969. It is likely to be of interest to American readers not only as an indication of current West German thinking on government organization and reform, but also because of the comparative insights it affords.

Students of government reorganization in the United States will recall that the Brownlow Committee appointed by President Roosevelt in 1936 consisted of three eminent Wise Men (Brownlow, Merriam, and Gulick) in academic and civic research organization positions, assisted by a relatively small staff of experts with similar backgrounds. Not so well known, perhaps, is the fact that Louis Brownlow found it "impossible to get any presidential funds for study abroad" and that Lindsay Rogers, whose work on British and French central administrative institutions was considered to be of signal importance for the President's Committee on Administrative Management, could not be appointed to its staff. ${ }^{3}$ While this hurdle was to some

\footnotetext{
* The manuscript of this article has been checked for factual accuracy by the Federal Chancellor's Office of the Federal Republic of Germany. However, the author is, of course, exclusively responsible for all evaluations.

* Professor of Law, Duke University.

${ }^{1}$ See especially Chancellor Brandt's policy statement of October 28, 1969, conveniently reproduced in Die Welt, October 29, 1969 (Air Mail Edition); English translation in I7 Trre BuzIETIN No. 4 (Supp. 1969).

${ }^{2}$ See Der SPIEger, Aug. 25, I969, at 26-27.

${ }^{3}$ L. Brownzow, A PASsion FOR ANOMYMTtx 353 (1958). For a collective biography of the Brownlow Committee, see B. Kari, Executtve Reorganization and Reford in the New Deal. The Genests or Admenstrative Management, 1900-1939 (1963).
} 
extent bypassed by the use of outside funds, the classic Report of the Brownlow Committee does not contain any foreign country materials and shows little overt evidence of the influence of comparative studies. ${ }^{4}$

By contrast, the West German Project Group consisted of ten senior civil servants, headed by an official of the Chancellor's Office and composed of representatives of the ministries that made up the Cabinet Committee, plus a delegate of the Federal Accounting Office who, like his chief in the Cabinet Committee, participated in an advisory capacity only. ${ }^{5}$ It thus corresponds more nearly to an Inter-Agency Task Force in the United States. The Project Group had its own Secretariat, conducted extensive investigations, and was solely responsible for the report ultimately submitted. Nevertheless, it obtained voluminous information and some advice from a dozen consultants. These consultants were mainly German political scientists and academic lawyers (two of the latter, including the present author, teaching in the United States); and the substantive topics of their reports ranged from the process of political decision making on the Land (state) level to systems analysis. There are no less than seven country studies: one each on Austria, Italy, Switzerland, France, and Great Britain, and two on the United States. ${ }^{6}$ These studies were given careful and sometimes detailed attention in the report of the Project Group. It is perhaps worth noting that at least four of the twelve consultants received part of their training in law in the United States, and that a fifth is an English professor of political science. ${ }^{7}$

The following is a brief survey of the first report of the Project Group and of

A classic example of the indirect influence of another system of government is the famous recommendation of the Brownlow Committee that the President be given a small number of executive assistants who "should be possessed of high competence, great physical vigor, and a passion for anonymity." THEE President's Committee on Administrative Management, Report of the Commitree 5 (i937). This language was apparently first used by Tom Jones to describe Sir Maurice Hankey. In a message sent via Mr. Brownlow to President Roosevelt in summer, I936, Mr. Jones had expressed the opinion that the President would best solve his problem by finding "that one man who would turn out to be another Maurice Hankey." Brownsow, supra note 3 , at $357,38 \mathrm{I}, 396-97$. See also KARL, supra note 3 , at 230, 282 n.20; T. Jones, A DiARy With LetTers, I93I-I950, at 216, 307-08, 3 I2-I3 (I954).

The Cabinet Committee consisted of Chancellor Kiesinger and the Ministers of or for Interior, Justice, Economics, Federal Questions, Scientific Research, and Finance, as well as the President of the Federal Accounting Office. For details, see I Projertgruppe für Regierungs- und Verwaltungs-

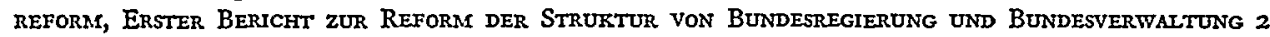
(rg6g) [hereinafter cited as FIRsT REPORT]. See also Theis, Reformen im Regierungssystem der Bundes. republik, 20 Aussenpolitik 677; Theis, Führungsinstrumentarium und politische Planung, id. at 735 (1969); Theis, Stand der Überlegungen zur Regierungsreform in Bund, 3 DIE VerwaltuNG 72 (I970)the first reports by an insider.

${ }^{\circ}$ Reports on Austria, Italy, Switzerland, and France by Professor I. Seidl-Hohenveldern, University of Cologne, 2 FIRsT REPORT I, 35, 7I, IoI; on Great Britain, by Professor Nevil Johnson, University of Warwick, id. I33; and on the United States, by Dr. Christian Determann, Yale Law School, and by the present author, id. at $180 \& 205$.

7 These are Determann, Baade, Scharpf, and Friauf; and Johnson (see note 6 supra). The then Minister of Justice and the present Minister in the Chancellor's Office, Professor Horst Ehmke, has also studied in the United States and is a noted authority on American constitutional law. See H. EFIMrE, WIRTSCHAFT und Verfassung. Die Verfassungsrechtsprechung des Supreme Court zUR Wirtschaftsregulierung (196r); Ehmke, "Delegata Potestas non Potest Delegari," A Maxim of American Constitutional Law, 47 CORNELL L.Q. 50 (Ig6r). 
official reactions thereto, and a discussion of the importance of comparative and country studies for this project. In conclusion, an attempt is made to relate the present stage of West German government reform more closely to the United States, using as a background the present author's memorandum to the Project Group, entitled "The Constitutional Position and the Government Machinery of the President of the United States."

\section{The Frrst Report: Government Reorganization}

The First Report of the Project Group for Government and Administrative Reform, dated August 3I, I969, consists of two volumes, 273 and 68r pages in length. The former contains the Report itself, and the latter, called "Appendix," reproduces the consultants' studies.

In agreement with the Cabinet Committee, the Project Group limited its investigations to three topics: (I) the delimitation of the spheres of competence of the federal ministries; (2) parliamentary secretaries, ministers of state, and ministers without portfolio; and (3) the improvement of the governmental machinery of the Federal Chancellor and Government. Its recommendations were made against the background of three policy decisions of the Federal Cabinet and the Cabinet Committee. First, there were to be no amendments to the Basic Law (or West German Constitution) until Fall, Ig6g. Second, the Project Group was to set out alternative courses of decision. Third, its recommendations were to take account of preexisting reform measures, and not to prejudice future, more comprehensive reform measures. ${ }^{8}$

\section{A. Reorganizing the Federal Ministries}

By way of introduction, it should be pointed out that the reorganization of the federal government in West Germany, including not only the transfer of functions from one agency to another but also the creation, fusion, or abolition of federal ministries, is basically a preserve of the Executive. The latter's competence in this area is limited only by specific legislative acts of an organizational character whichat least in the absence of appropriate delegations of authority-are binding upon the Executive until or unless amended or repealed, and the general necessity of obtaining Parliamentary approval for budget positions." This latter, in effect, prevents the creation of permanent positions without approval by Parliament. In a Parliamentary system of government, which is premised on the support of the government of the day by a working legislative majority, these two limitations are hardly of overriding significance.

Furthermore, a newly elected Parliament votes only on the Chancellor, not his

\footnotetext{
${ }^{8}$ I FIRST RePoRT, supra note 5, at 3-5.

- See generally E. Böckenförde, Die Organtsationsgewatti im Bereich der Regierung (I964).
} 
Cabinet; and the Chancellor-elect is subject only to political, not to legal, restraints in his initial decision as to the composition of the Cabinet and the number as well as the functions of the Ministries to be kept or created.10 Thus, with a new Federal Government to be constituted in Fall, I969, and with a reasonably broad mandate for reform, the Project Group had considerable leeway in its recommendations on reorganization.

\section{The Proposals}

The Project Group proceeded from the basic premise that the composition of the Cabinet should be governed by four principles, which were to some extent in conflict: First, there was to be a division of labor by the allocation of discrete spheres of competence. Second, it was desirable to maximize the participation of politically potent powers in the Cabinet. However, third, the effectiveness of the Cabinet as a decision-making body was not be jeopardized by too large a number of Cabinet positions; and, finally, excessive subdivisions of spheres of competence were to be avoided.

There was widespread agreement among the politicians and senior civil servants

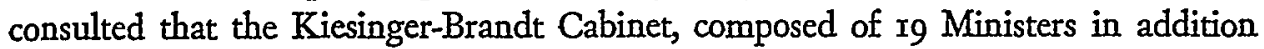
to the Chancellor, failed to meet the third requirement just listed. Although noting the absence of hard evidence, the Project Group tended to agree with this judgment. However, it rejected the optimum size of collective decision-making organisms, put at seven to nine by modern organization theory, as too small for present purposes. Such a group could not represent the entire political Executive of a complex modern industrial state like the Federal Republic of Germany. (It will be noted that the Federal Cabinet is a constitutional organ of prime importance in West Germany; this will be developed in detail further below. ${ }^{11}$ )

Instead of seeking to establish optimum Cabinet size at the outset, the Project Group proceeded directly to the study of the existing organization chart of the federal ministries, with a view to determining where there was room for the consolidation of functions and the abolition of redundant agencies. Among the advantages to be derived from such consolidations, it noted the reduction of jurisdictional disputes, of duplication, and of the necessity for coordination at the Cabinet level; greater flexibility in assigning priorities within large organisms; more possibilities for the delegation of tasks to subordinate units; and savings in personnel through the elimination of central administrative agencies.

On a somewhat higher level, the rational consolidation of functions was to lead to a reduction of imbalance between the various ministries, the allocation of competences by "task affinity," and the realization of the optimal size of ministries, taking into account existing possibilities for reducing the workload of cabinet

\footnotetext{
${ }^{10}$ For a recent summary, see Rein, Die verfassungsrechtlichen Kompetenzen des Bundespräsidenten bei der Bildung der Bundesregierung, I969 JURISTENZEITUNG 573.

${ }^{11}$ See p. 637 infra.
} 
ministers. As regards the factor of imbalance, the Project Group rejected the "budget slice" of the various ministries as a dependable criterion. The number of senior civil servants was a more reliable factor, but the ultimate decision would have to rest on the relative political weight of each individual ministry.

In accordance with its mandate to proceed on the basis of existing structures, the Project Group accepted as given the continued existence of a certain number of ministries. These included the five "classical" or "of" ministries based on the Prussian constitutional tradition: the Foreign Office and the Ministries of Interior, Justice, Finance, and Defense. Among the so-called "neo-classical" ministries, i.e., those "for" ministries that antedate the establishment of the Federal Republic, nobody among those interviewed had raised doubts as to the continued existence of the Ministries for Economics, Agriculture, Labor, and Transport. Furthermore, in view of the present preeminent importance of science and technology for modern industrial society, the Project Group added the Ministry for Scientific Research to the organizational core.

That left nine minstries as potential candidates for dissolution. Only one of these, the Ministry for Postal Services and Telecommunications, was neo-classical; the remaining eight were what has become known as "prefab" ministries, i.e., creations of political expediency or necessity since 1949. One of these, the Ministry for All-German Affairs, was declared as off limits: due to the special and delicate nature of intra-German relationships, the tasks of this ministry could not be allocated to the Foreign Office or the Ministry of Interior. This decision was candidly acknowledged to rest on political grounds.

The seven "prefab" ministries marked for possible extinction, along with Postal Services and Telecommunications, were Health, Economic Cooperation, Treasury (Federal Property), Housing, Refugees, Federal Relations, and Family. Since the Project Group refused to accept the premise that the public importance of a specific task area was as such sufficient justification for the establishment of a separate cabinet ministry, ${ }^{12}$ it did not hesitate to tear down the "prefabs." All three of the alternative models proposed provided for their elimination. Postal Services and Telecommunications was spared on the ground that its abolition might prejudice more general reforms. Furthermore, it was suggested that cabinet-level status might be desirable in view of the international operations of the postal and telecommunication services.

The minute details of the three alternative reorganization schemes suggested are hardly of interest here. The third model, envisaging twelve cabinet ministries, would integrate the various "prefab" ministries into the existing classical and neoclassical ministries; the Ministry for Federal Affairs was to be merged into the Chancellor's Office under all three models. The first and the second models, each calling for thirteen cabinet ministries, contemplated the creation of one new min-

\footnotetext{
${ }^{12}$ First Report yo. See also p. 658 infra.
} 
istry, termed Ministry for Social Affairs or Ministry for Structural Planning, respectively. The Ministry of Social Affairs (Model I) would encompass the entire former Family Ministry; the Home Construction Division of the Housing Ministry; and the Human and Veterinary Medicine and Food divisions of the Health Ministry. The Structure Ministry (Model II), on the other hand, would consist of the Health Ministry's Water, Air, and Noise Division and all divisions of the Housing Ministry. All three plans envisaged the merger of the Economic Cooperation Ministry into the Foreign Office, and the Refugee Ministry into the Ministry of Interior. The latter was by far the largest beneficiary under all models; its senior staff would grow from the present level of 254 to 340,380 , and 480 , respectively, under Models I, II, and III.

Since these plans were elaborated in constant contact with those directly affected, the Report already reflects some reaction to the proposals that were to emerge. The Ministries for Economic Cooperation and of Housing submitted detailed statements of their positions. Far from being resigned to its fate, the former asserted that optimal efficiency in the area of foreign assistance required the abolition of Foreign Office tutelage as well as the transfer of capital assistance functions from the Ministry for Economics. In the judgment of the Economic Cooperation Ministry, a cabinet of "about 15 " would still be able to function as an effective policymaking unit. ${ }^{13}$

The Family Ministry, on the other hand, conceded that initial expectations in the special efficiency and drive of small ministries created for particular tasks had not been justified by experience, and that these special tasks would have been pursued with better results by a larger ministry with major subdivisions. It nevertheless opposed the consolidation of all the "prefabs" into one super-ministry, and proposed the creation of a Ministry for Social Affairs that was to be roughly of the same political importance as the Ministry of Labor, and which would encompass all areas of social policy not covered by the classical and neo-classical ministries. This would include family, youth, sports, health, and social and housing assistance.

The Project Group rejected the proposal of the Economic Cooperation Ministry as unsound, and incorporated the Family Ministry's suggestion into its Model II. It also rejected a proposal by an interest group for the creation of a Ministry for Construction on the same grounds that led to the rejection of all strictly technocratic ministry models.14 Nevertheless, all three concrete proposals for reorganization were to achieve almost total success. ${ }^{15}$

In addition to the major task of reducing the number of ministries through consolidation, the Project Group also discussed several proposals for the transfer of functions between ministries that would continue to exist. It made several recom-

\footnotetext{
${ }^{23}$ Communication from the Ministry for Economic Cooperation, of July 31, I969, I FrRst REPoRT I34; and of May 28, 1969, id. at IIO, 130 .

14 See id. at 32-33.

${ }^{25}$ See p. 632 infra.
} 
mendations in this connection, with Models I and II calling for more shifts than Model III. These proposed transfers of divisions and subdivisions do not seem to be of major independent significance. The Project Group expressly rejected a suggestion that monetary policy be concentrated in the Ministry of Finance so as to deprive the Ministry of Economics of its key position in macro-economic planning. It also rejected a proposal to transform the Ministry for Scientific Research into a Ministry for Science and Technology, with responsibility not only for research planning and subsidy, but also for the economic exploitation of advances in technology. However, there was a strong collective dissent on this point from within the Project Group itself. An individual dissent, also relating to this area, called for a radical reorientation of educational and training policy in science and technology, with emphasis on all levels rather than extrapolations from the university prototype. ${ }^{10}$

On a different level, the Project Group opposed the establishment of a Coordination Ministry; experience had shown that coordination among equals was beset with too many difficulties. ${ }^{17}$ While noting, and approving of, consultation arrangements between individual ministries, the Project Group also recommended against extensive use of standing cabinet committees. This would, in its judgment, not only unduly tax the time schedules of the ministers and thus lead to stand-in representation by senior civil servants without political authority, but would also limit the information level of ministers who were not members of the committees.

\section{Implementation by the Brandt Government}

Some indications of the effect of the recommendations of the Project Group can be gathered from the cabinet list as approved on October 22, and from the new Government's first policy statement before Parliament on October 28, 1969. The Federal Cabinet now consists of ${ }_{5} 5$ ministries, or perhaps more accurately, $x_{4}$ ministries and 15 ministers. Besides the five classical "of" ministries, it includes six of the seven previous neaclassical ministries. Postal Services and Telecommunications has lost ministry status after all, and is currently merged with Transport. Among the "prefab" ministries scheduled for liquidation by the Project Group, Home Construction and Economic Cooperation survive. The former was originally scheduled for extinction but was saved by a massive "mayors' revolt."18 There is a new Ministry for Health, Family, and Youth, indicating the more or less general acceptancesubject to the exceptions noted-of the Project Group's Model I, which also appears to be the one preferred by it. The Chancellor's Office is now headed by a cabinet minister-the former Minister of Justice who was one of the members of the original Cabinet Committee of seven. The Ministry for Scientific Research has been renamed Ministry for Science and Education, which indicates some responsiveness

\footnotetext{
10 I FIRST REPORT 59-60, 68-7I.

${ }^{17} I d$. at 21 . See also pp. 659,660 infra.

${ }^{18}$ Eschenburg, Bonns kleine Kabinettsteform, DIE ZEIT, December 23, I969, at 6.
} 
to the ideas expressed in the lone dissent on educational policy in the Project Group's First Report. ${ }^{19}$

In his policy statement of October 28, Chancellor Brandt stated that "a government talking reform has to start with itself." He mentioned the reduction in the number of ministries and a first reorganization of competences that had already taken place, and pledged continued efforts to "delineate responsibilities more clearly and to avoid duplications of effort." The structures of the Chancellor's Office and of the Ministries are to be modernized along with their working methods; and Parliament has been promised not only a new table of organization, but also a listing of the composition and the spheres of competence of the Cabinet Committees that had been established by the new government. The Post Office is to receive new legal status with a view to assuring sound management along business lines. As regards education policy, the Chancellor came very close to the ideas expressed by the dissenter in the Project Group; and his emphasis on the interaction between scientific research and economic development appears to parallel the views of the collective dissent. ${ }^{20}$ Nevertheless, it seems quite clear that internal economic development through technological innovation will remain a primary responsibility of the Ministry for Economics. ${ }^{21}$

A press report notes that the Brandt Government's reorganization of the cabinet and reassignment of functions among the surviving ministries "largely corresponds to the plans elaborated by the Project Group for cabinet reform." It thus seems that so far as reorganization is concerned, the First Report of the Project Group has been remarkably successful. Despite the survival of two ministries marked for extinction by it, even the Project Group's estimate of senior personnel savings through the elimination of central administrative agencies, placed at between 80 and roo (out of a total of 5,248), appears to have been remarkably accurate. ${ }^{22}$

\section{B. Strengthening the Political Executive}

In keeping with the Prussian tradition of government organization, the prototype of a West German federal ministry consists of several divisions (Abteilungen), each of them subdivided into sections (Referate). These are headed by senior civil servants, with a State Secretary at the summit of the hierarchical pyramid. The State Secretary is a so-called "political" civil servant, as are, under the law, but to a much lesser extent in practice, the Ministerial Directors who head the divisions. This means that they can be dismissed for purely political reasons at any time, subject, however, to very considerable civil service "waiting status" or retirement benefits.

\footnotetext{
${ }^{10}$ See p. 632 supra. For the cabinet list, see DiE WeIT, October 22, 1969, at I (air mail edition).

so See p. 632 supra; section VIII of Chancellor Brandt's policy statement of October 28, 1969, supro note I. All translations from the German are the present author's.

$21 \mathrm{Id}$. at $\S \S \mathrm{V}$, VIII.

${ }^{23}$ Zundel, Kabinettsverkleinerung in Bonn, DIE ZEIT, November 4, I969, at $\mathrm{r}$.
} 
The Brandt Government has made use of its dismissal powers with respect to Ministerial Directors in only eleven cases (out of a total of IIO).

Almost invariably, the Ministerial Directors achieve their positions by merit promotion from within; lateral movement is very limited and entry from the outside at this level, quite exceptional. The State Secretary, who is the administrative head of the ministry and the regular representative of the minister, usually shares the fate of his immediate superior, as, seemingly, did all State Secretaries in CDU. headed ministries in the Fall of 1969 . He is frequently brought in from the outside, and will have some likelihood of a similar appointment when his term is ended for political reasons. Since federal laws are normally executed by the states in their own rights, the corresponding positions in state government are not unattractive, as are even some top positions in municipal government. Despite this high-level fungibility dependent upon political alignments, the typical West German State Secretary at the head of a federal ministry has a career civil service background.

This system has produced some of the best statesmen-bureaucrats in history. It has also suffered some of the most ineffectual cabinet ministers. "Don't tell me what to sign; just tell me where to sign," is a German old saw directed at cabinet ministers; and the traditional view of Prussia-Germany at its peak is that of a "Beamtenstaat"-a bureaucratic state.

The disadvantages of such a system are known, or at least suspected, since Max Weber's famous polemic. ${ }^{23}$ However, it was not until the formation of the KiesingerBrandt coalition and West Germany's secular decision for the modern positive welfare state that serious efforts were made to strengthen, in a systematic manner, the political component of the federal Executive.

The Parliamentary State Secretaries Act of April 6, 1967, provides for the appointment, from among the members of Parliament, of parliamentary state secretaries, to serve at the pleasure of their respective cabinet ministers. The functions of these secretaries are not defined in the Act itself. However, its legislative history indicates substantial agreement to the effect that they were to ( $I$ ) assist cabinet ministers in their political activities, and thus strengthen political leadership within the Executive; (2) in particular, maintain and improve contact with Parliamentary institutions, political parties, and the public; (3) relieve cabinet ministers of duties primarily of a ceremonial nature; and (4) obtain the chance to gather experience for a subsequent cabinet-level political career. ${ }^{24}$

In the Kiesinger-Brandt Government, parliamentary state secretaries were appointed for the Chancellor's Office, the Foreign Office, and five other ministries:

\footnotetext{
${ }^{23}$ Note especially ch. II-IV of his ParLament und Regierung im neugeordneten Deutschrand rcv. ed. I918), conveniently found in M. Weber, Gesammelte politische Schriften 294, 299 et seq. (J. Winckelmann, 2d ed. r958).

${ }^{24}$ I FIRST REPORT I42-45; see generally Wahl, Die Weiterentwicklung der Institution des Parlametarischen Staatssekretärs, 8 DER STAAT 327 (1969); H. LAUfER, DeR ParLaArentarische StaAtsSEKRETÄR (Ig6g).
} 
Interior, Finance, Economics, Defense, and Transport. Thus, at the time of the preparation of the Project Group's first report, an appraisal of the functioning of this new political office in the West German federal system had to be based on slightly over two years' experience in substantially less than half the ministries.

A basic premise of the Project Group Report is that its recommendations on ministry reorganization described above, as well as its proposals for the improvement of the instruments of government of the federal Executive to be discussed further below, are inseparably linked to the need for increasing the political efficiency of individual cabinet ministers. Thus, its approach to the subject of parliamentary state secretaries is generally characterized by a desire to strengthen a budding political institution, taking into account all relevant experience to date.

The Project Group gathered quantitative data as to the politically significant activities of the parliamentary secretaries of state, and gathered additional information through detailed questionnaires. Its most significant finding was that the parliamentary state secretaries had virtually replaced the civil servant-state secretaries as their ministers' representatives in Parliament, especially in question period activities. In addition, the Parliamentary State Secretaries of the Finance and Interior Ministries had made statements of Government policy in Parliament; and the latter had, a few times, delivered the opening statements in support of Government bills. ${ }^{25}$

As regards cabinet affairs, the record was somewhat uneven. In accordance with $\S 23$ of the then current Rules of Procedure of the Federal Cabinet, only the Parliamentary State Secretary of the Chancellor's Office was regularly entitled to attend all cabinet meetings. Cabinet ministers not in personal attendance could authorize either the Parliamentary State Secretary or the (civil-service) State Secretary to attend; in the absence of specific ministerial direction, the latter attended. A minister attending a cabinet meeting may, at his choice, be accompanied by either his parliamentary or his civil-service state secretary, but not by both at the same time. Attendance at cabinet meetings by persons other than the Chancellor and cabinet ministers is for purposes of information only. In view of the constitutional nature of cabinet membership, only a minister may hold another minister's proxy for purposes of cabinet decision.

The figures compiled by the Project Group indicate that only the Parliamentary State Secretaries of the Chancellor's Office and the Foreign Office were more or less regularly in attendance at cabinet meetings, although by no means at all of them. The record of the other Parliamentary State Secretaries in this respect is quite uneven. In one case (Interior) there was a striking reduction in attendance, seemingly coincidental with a change in personnel. ${ }^{26}$

A more important issue, expressly left open in the Ig67 law despite initial government wishes to the contrary, is the position of the Parliamentary State Secretary

\footnotetext{
${ }^{35}$ I FIRST REPORT I48-53 and tables I-III thereat.

${ }^{20}$ Id. at $\mathrm{r} 53$ and table III.
} 
within each individual ministry, and especially his relationship to the (civilservice) State Secretary. Here, responses to the pertinent six-question segment of the Project Group questionnaire reveals identical practices in only three respects. All Parliamentary State Secretaries were entitled to information and access to the files pertinent to their assigned tasks; all regularly received information on all matters of political or basic significance; and-most significantly-all Parliamentary State Secretaries conducted their relations with their respective ministries exclusively through the conduit of the (civil-service) State Secretary. The Project Group further determined that none of the Parliamentary State Secretaries had been assigned a position that made his office an additional level in the ministry's hierarchy. However, in three ministries, they had been given operative tasks, and were entitled to issue directives (through channels) within the scope of these tasks. Other divergencies relate to the channelling of official papers to the minister from below. In one ministry, these had to go through the Parliamentary State Secretary; in three others, he routinely received copies. ${ }^{27}$

The Project Group recommended that Parliamentary State Secretaries be appointed for all federal ministries; that they be placed in the minister's office so as not to constitute a new level in the ministry hierarchy, and that they be qualified, as before, to assume direct operational tasks at the specific direction of their respective ministers, but only through regular channels, i.e., through the (civil-service) State Secretary. None of these changes required additional legislation. In addition, however, the Project Group also recommended that the Parliamentary State Secretaries be redesignated Ministers of State, and that their selection not be confined to members of Parliament. The former would underline the political nature of the office and possibly add weight to its representational qualities, especially on the international level; the latter would enlarge the scope of political recruitment and at the same time mitigate against the danger of talent depletion in the parliamentary party of the government of the day.

The two recommendations last mentioned would require legislation, which has not as yet been sought. The other recommendations of the Project Group have gained ready acceptance by the Brandt Government. Parliamentary State Secretaries have been appointed for all cabinet positions; their rank initially included Professor Ralf Dahrendorf, the noted sociologist and political "idea man" of the minor coalition partner. This evidences a basic decision in favor of further strengthening the political Executive at the cabinet ministers' level through the expansion of the role of the Parliamentary State Secretaries. Furthermore, the Rules of Procedure of the Federal Government have been amended so as to make the Parliamentary State Secretary the regular representative (to the extent constitutionally possible) of his Minister before both Houses of Parliament and in the Cabinet, and to render him independent of the civil service State Secretary with respect to within-Ministry

\footnotetext{
${ }^{27} \mathrm{Id}$. at $\mathrm{I}_{4} 8-50$ and table I.
} 
administrative tasks (including the operative supervision of Divisions) specifically delegated to him by the Minister. ${ }^{28}$

II

\section{Political Planning for the Seventtes}

\section{A. The Frame of Reference}

The Project Group had initially been assigned two tasks in addition to government reorganization and the strengthening of the political Executive. These were improvements in the governmental machinery of the Chancellor and in the functioning of the Cabinet. However, in due time, these latter two topics came to be regarded as so intimately interconnected that the Report treats both of them under the collective heading "Improvement of the Governmental Machinery of the Federal Chancellor and Government."

\section{Constitutional Considerations}

To some extent, this fusion of assigned topics was influenced by constitutional considerations. The mandate of the Project Group, it will be recalled, specifically excluded recommendations requiring amendments of the West German Basic Law, or Constitution, for their implementation. Thus, the balance struck between the various components of the political Executive by article 65 of the Basic Law had to be accepted as given for present purposes. Article $6_{5}$ is to a large extent the legacy of Bismarck's unique combination of Prussian and Federal elements in the I87I Constitution, with some accretions in later years. ${ }^{29}$ It contains three basic principles governing competence within the political Executive which appear to import separation-of-powers thinking into the realm of one of the classic component powers. The first is the Chancellor Principle: the Chancellor determines the directives of government policy. The second is the Department (Ressort) Principle: within the framework of these directives, each cabinet minister has individual authority and responsibility in the administration of his department. The third is the Cabinet Principle: differences of opinion between cabinet members (but not between the Chancellor and one or more cabinet members) are resolved by the cabinet, which consists of the Chancellor and the ministers.

The Chancellor's power to determine general governmental policy is augmented by what has been termed the substantive cabinet formation power of the Chancellorelect. The latter includes decisions as to the number of ministries and the delimita-

\footnotetext{
${ }^{28}$ Zundel, Kuddelmuddel um Minister-Stellvertreter, DrE Zerr, December 23, I969, at 6; 23 of the Rules of Procedure of the Federal Government, as amended on February 19, I970, conveniently reproduced in U. Echter \& H. LAUfer, Regieren im VerfassungsstaAt 252, 258-59 (1970). For a recent account, see DER SPIEGEL, March I, I97I, at $4 \mathrm{I}-43$.

20 E. Junker, Die Richtutntenkompetenz des Bundeskanzaers 4-44, 70-75 (1965). Cf. Menzel, Die heutige Auslegung der Richtlinienkompetenz des Bundeskanzlers als Ausdruck der Personalisierung det Macht? 2 Die MOderne Demoxrstie und IHR Recht 877 (Ig66).
} 
tion of their functions, as well as the selection of incumbents. A necessary corollary of these powers, not spelled out in the Basic Law itself but generally recognized by accepted authorities, is the power to secure the dismissal of individual ministers after the process of cabinet formation has been completed.

Still, the department and cabinet principles are more than mere ornamental trappings of what has been referred to as a "Chancellor's Democracy." The cabinet principle is of special vitality, since virtually every important political action by the Executive is termed a Government action by the Basic Law, and hence requires a cabinet decision. There might be more doubt as to the value of the department principle; attempts by constitutional lawyers to endow it with justiciable constitutional protection have met with some levity by seasoned political observers. Nevertheless, it is quite clear that all three principles enunciated by article 65 of the Basic Law are constitutional principles; and that at least in theory, they can be enforced by constitutional adjudication which in West Germany extends to jurisdictional disputes between organs of government. Much more importantly, it is also generally recognized that while the working interrelationship of these three principles shifts from time to time and in response to political and personality factors, there is a general obligation of constitutional magnitude not to create additional imbalances through organizational devices. ${ }^{30}$

To sum up: the Project Group had no mandate to recommend changes of the Constitution, and thus necessarily had to shun all schemes that would permanently dislocate the precarious but nevertheless constitutionally ordained balance between the Chancellor, the individual cabinet ministers, and the Federal Cabinet as an aggregate political organ. This meant, as a practical matter, that the task of improving the efficiency of the Chancellors' Office could not be pursued independently of the objective of making the machinery of the cabinet more effective. (The Department Principle had already received special attention in the portions of the Report dealing with reorganization and, more particularly, parliamentary state secretaries and ministers of state.)

\section{Intermediate-term Budget Planning}

In addition to the above-discussed constitutional constraints, the Project Group was subject to the cabinet's directive that preexisting reform measures be taken into account. Chief among these was intermediate-term budget planning-a secular contribution of the Kiesinger-Brandt Government to the West German political system.

Students of public administration will recall that in August, I965, President Johnson had directed the extension of the Planning-Programming-Budgeting System to all federal departments and agencies. Almost exactly one year later, an astute man-

\footnotetext{
${ }^{30}$ See the consultations of Professors Klaus Stern and Heinrich Friauf, both of the University of Cologne, in 2 FiRst REPORT 563, 607.
} 
agement analyst could still confidently observe, with respect to West Germany: "Politically, any overt extension of programming or planning schemes is less feasible now than it has even been."31 West Germany was regarded as fully committed to the "Politics of Non-Planning," and even a leading expert study of budgetary processes, while recommending intermediate-term budget planning at the federal level, had carefully added that this would be for informative forecasting purposes only. It solemnly warned against any attempt to make forecasting the basis of control "by any means," and against any far-reaching subdivision of the data, "or else the market economy would be in danger."32

Endangered, indeed, it was. Late in I966, the holy cow developed lactation problems; and almost overnight, everything changed. West Germany's economic recession was reflected in the governmental sector by a budget crisis. Public disclosure of a monumental overestimate of revenues not only brought down the government of the day, but also gravely impaired confidence in the budgetary tools and methods then available and practised. The Kiesinger-Brandt Grand Coalition Government that took office on December I, I966, was indeed not so much a product of coalition arithmetic as the political expression of a general realization that radical governmental reforms were called for. In a federal state saddled with the legacy of a paleo-liberal ideology with pretensions of constitutional anointment, such reforms could only be achieved by a government that commanded the requisite support for amending the Basic Law practically at will. While a coalition backed by over 90 per cent of Parliament was clearly recognized to be a serious deviation from the norm of responsible parliamentary government, this deviation was expressly accepted, on a temporary basis, as the only device suited to bring about the basic reforms now demanded by all concerned.

The Kiesinger-Brandt Government promptly secured a constitutional amendment designating macro-economic equilibrium as a goal of federal and state budget making, and authorizing Parliament to enact guidelines for anti-cyclical budget management as well as "budget planning for periods of several years." This express constitutional recognition of planning as a governmental task was accompanied by the Act of June 8, r967, for the Support of Economic Stability and Growth. The latter lists four specific budget planning goals: price stability, high-level employment, foreign trade equilibrium, and economic growth. The Government is directed to elaborate and to lay before Parliament intermediate-term budget plans. These plans cover periods of five years, and are regularly adjusted in the light of subsequent insights and developments. Federal ministries are directed to maintain investment plans on a current ten-year basis. ${ }^{33}$

\footnotetext{
${ }^{31} \mathrm{H}$. ARndt, West Germany: Politics of Non-Planning 122 (I966).

${ }^{32}$ Quoted in id. at 99.

${ }^{38}$ See generally Stucken, Die Haushaltspolitik im Gesetz zur Förderung der Stabilität und des Wachstums der Wirtschaft vom 8. Juni 1967, 27 FINANZARCHT 202 (1968); Weichmann, Finanzplanung als staatliche Aufgabe, id. at 220; Hettlage, Probleme einer mehrjährigen Finanzplanung, id. at 234; and for
} 
Budgetary estimates are still prepared by the various ministries and revised, as well as coordinated, by the Budget Division of the Ministry of Finance. Intermediateterm budget planning is also initiated by a special subdivision of that Ministry, and then channeled through a Cabinet Committee headed by the Chancellor and composed so as to exclude the "major consumers" of federal funds. Initially, this Committee included the Ministers of and for Finance, Economics, Federal Property, and Federal Questions. While the Cabinet Committee is responsible for the coordination of the intermediate-term budget planning process and for the elaboration of alternative planning proposals, the ultimate power of political decision rests with the whole cabinet as a constitutional organ.

In the past, cabinet decisions in this area have consisted of ceilings for individual ministries worked out primarily on the basis of ministry estimates, but also incorporating decisions as to magnitude and priorities based on more general considerations of economic policy (e.g., high-priority support of transport and research). In time, and as experience accumulates, it is expected that decisions of the latter type will become the central factor in intermediate-term federal budget planning. ${ }^{34}$

The process of intermediate-term budget planning described above has now been extended to the states. A constitutional amendment of May I2, I969, authorizes federal legislation establishing common guidelines for the federal and state governments for budgetary law, anticyclical budget management, and multiple-year budget planning. An Act of August I2, I969, adopted just before the recess of Parliament precedent to the September elections, makes the adoption of intermediate-term budget planning mandatory on the state level as of January I, I972, and establishes a mechanism for joint state-federal budget policy making. ${ }^{35}$ These constitutional and legislative extensions of the intermediate-term budget planning system would appear to provide the federal government with an ideal panel of instruments for the economic and monetary policy guidance of a dynamic modern economy.

It is, perhaps, good to recall that on the eve of West Germany's constitutional crisis that triggered the developments here described, a senior official of the Bundesbank had pessimistically compared the federal administrative apparatus to a symphony orchestra which, while proficient in the classics and in the "popular operatic melodies" preferred by the Adenauer Government, was likely to reveal serious weaknesses when asked to perform modern compositions. Even a star conductor might

legal discussion, K. Stern \& P. Münch, Gesetz zuR Förderung der Stabilitït und des Wachstums DER WIRTSCHAFT ( 1967 ) and the minutes of the annual meeting of German academic constitutional lawyers in Bochum on October 3, 1968, with reports on Öffentlicher Haushalt und Wirtschaft by Professors Friauf and Wagner in 27 Veröpfentlichungen der Vereinigung deR Deutschen StaAtsRechtSLEHRER I \& 47 (1969). Friauf, id. at 10-39, furnishes exhaustive further references.

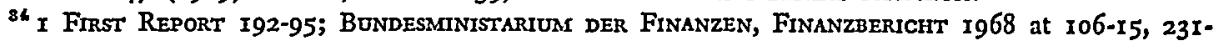
39 (1967). Cf. G. Denton, M. Forsyth \& M. Maclennan, Economic Planning and Policies in Brtain, France and Gerdany 227-29 (I968).

${ }^{85}$ Act of May 12, 1969, [1969] I BGBl. 357 (art. I09(3) of the Basic Law); Act of August 19, I969, [xg69] I BGBI. I273. 
fail before an orchestra that approached Schönberg, Bartok, or Stravinsky (scil. anti-cyclical economic policy, intermediate-term budget planning) with hesitation; "and let us remain politely silent about Stockhausen and Boulez (modern weapons systems; research planning)."36 Less than three years after this devastating indictment, the Project Group Report notes:

Intermediate-term budget planning is the most completely developed instrument of planning at the federal government level. In its methodology and technique, it occupies a leading place in the Western world even if compared to the PPB System of the United States federal government. ${ }^{37}$

\section{B. Goals and Critical Inventory}

The Project Group regarded its task of recommending improvements in the governmental machinery of the Chancellor and the Cabinet as tantamount to a mandate to develop organizational schemes for effective political planning by the Executive. It started with the assumption that only the service state is adequate to the needs of modern man in modern society, and that "the service state which actively shapes society . . . must increasingly develop a policy based on concepts derived from a comprehensive view of social, economic, and technological change, and thus able to constantly supply innovation impulses, i.e., impulses for new, consciously directed developments." 38 A few years ago, such a basic premise would have been rank heresy; today, it has become common property. The Project Group was even able to cite as authority a policy declaration by Chancellor Kiesinger on March II, Ig68.

But although the ideology of political planning had been received into conventional wisdom, government and administrative institutions had not fully responded to present-day requirements. The Project Group found that while on the whole, the West German system of government and administration was generally deemed to stand up to critical comparison with economic enterprises or with foreign political systems, it was quite widely regarded as unequal to the task of political planning as defined above. Critical voices referred to a basic style of pragmatic case-by-case reaction instead of the consistent pursuit of long-range policy; to the lack of adequate planning tools and methods in the Chancellor's Office, the Cabinet, and the ministries, especially as regards the basis of information; and to ambiguity and shortterm orientation of political goal decisions and value judgments of the Chancellor and the Cabinet. On a somewhat more technical level, there were complaints about the dual function of cabinet ministers, with department management encroaching upon political functions. The traditional bureaucratic apparatus of the ministries was felt to be unequal to its new tasks, prone to prefer quick compromise to the elaboration of political alternatives, and inclined to pursue its own goals or tradi-

\footnotetext{
${ }^{30}$ Hüttl, Koordinierungsprobleme der Bundestegierung, 6 DER STAAT I, I5-16 (1967) (manuscript of a lecture given on October 20, 1966 ).

${ }^{87}$ I First RePORT i92. See also id. at 244-45; p. 660 infra.

${ }^{38}$ Id. at 184 .
} 
tional tasks. The isolated creation of planning sections in various ministries was criticized as leading to imbalance in the Cabinet, and to patchwork rather than comprehensive planning.

This wide array of criticism was sufficient to induce the Project Group to undertake its own inquiries into the most important phases of the political decision process within the federal government. These inquiries revealed, in its judgment, that the traditional system had some inherent limitations which were bound to increase with further governmental expansion and compartmentalization. The subdivision and compartmentalization of substantive responsibilities within the hierarchical organization scheme of ministries was found to have no less than four dysfunctional effects upon the intake and the evaluation of information. Since information intake was determined by subject-matter competence, the perspectives of lower organizational units were necessarily limited. Routinization of the intake process was conducive to blocking both the intake and the evaluation of decisive information. Information tended to be more complete where there was pressure by social groups or organized interests; hence there was the danger of an information disequilibrium within the organization. This danger was further enhanced, finally, by the dominance of individual information preferences, made possible through the lack of a uniform information system.

On a somewhat different level, an increase in the number of organizational units was likely to limit the interaction between leadership and the line, thus further enhancing the significance of the value preferences of individual line officials in the decisional process. Finally, there was a general lack of organizational units for the elaboration of long-range perspectives. Planning staffs presently in existence were plagued by limitations of substantive competency; lesser units were too hard-pressed by routine duties to make significant contributions to the process of long-range goal definition.

The Project Group found that some of these difficulties inherent in the hierarchical compartmentalization of ministries had been mitigated by the increasing use of inter-ministry committees. ${ }^{39}$ Still, in its judgment, this committee device was unlikely to be a satisfactory tool for the collective shaping of a concept-oriented policy. The prevalent technique of assigning the chairmanship ((Federfïhrung) to the ministry most directly concerned tended to favor competence-oriented bureaucratic thinking; and chairmen were likely to keep their committees as small as possible, thus minimizing conflicts of interests or potential conflict situations. Standing committees might be more useful, but in addition to the difficulties just mentioned, the limited powers of the participants militated against the development of innovative functions. ${ }^{40}$

\footnotetext{
${ }^{30} \mathrm{Sec}$, in this connection, H. Prior, Die Interministerielden Ausschüsse der Bundesministerien (I968).

${ }^{40}$ I First Report I88-89.
} 
Probably the most devastatingly negative finding of the Project Group concerns the control of political decision making. Current mechanisms were mainly limited to controlling the administrative execution of the measures decided upon; this was true even as regards budget control. In the absence of sufficiently clear definitions of the goals to be achieved, there could be little if any control of the efficiency of actions in terms of purposes.

This searching critique of extant instruments for policy planning was to some extent counterbalanced by the conclusions derived from the foreign-country and West German State studies commissioned by the Project Group. These showed, in its judgment, that the problems found to exist in the West German federal government were also to be found, to a lesser or greater extent, in these other systems of government; that certain peculiarities were essentially the products of historical developments; and that all governments included in the survey were facing new tasks that required adaptations of the traditional systems of government. The most important finding in this regard deserves quoting in full:

The constitutional position of government institutions is only of minor significance in relation to existing inadequacies. Comparable deficiencies are found in the Presidential, Cabinet, and Chancellor systems. Therefore, none of the problems could be solved merely by, for instance, introducing the Presidential system in the Federal Republic. ${ }^{41}$

\section{Improving Policy Planning Through Reorganization}

\section{Policy Planning and Budget Planning}

As already mentioned, West Germany has an intermediate-term budget planning system which compares favorably, in the opinion of the Project Group, to the PPB System at its current stage of development in the United States. Since reform proposals were to be integrated, so far as possible, into pre-existing reform programs, an obvious question was whether the intermediate-term budget planning system might serve as the nucleus for a general policy planning system. The Project Group considered this possibility at some length, and arrived at a negative conclusion.

In essence, the view prevailing would appear to have been that policy planning and budget planning are complementary but not coextensive; that both derive advantages from a dialectical relationship based on independence but interdependence; and that both would suffer from the fusion of budgetary and political planning processes. Budget planning took no account of nonmonetary capacities; it was geared to relatively short-term sequences (five years). An expansion of its functions would necessarily lead to the inclusion of the "largest consumer" ministries in the Cabinet Committee for intermediate-term budget planning. This would be highly undesirable. Furthermore, the preeminent position of the Finance and, to a lesser extent, the Economics Ministries in intermediate-term budget planning

\footnotetext{
11. at 190. See also p. 659 infra.
} 
would not be extended to policy planning as such without strong resistance to the notion of an "inner cabinet" which was in derogation of the cabinet principle (article 65 of the Basic Law).

Another reform proposal called for the transfer of intermediate-term budget planning responsibilities from the Ministry of Finance to the Chancellor's Office. This proposal, and even a more modest variant which called for the transfer of Federfïhrung to the Chancellor's Office, did not find the Project Group's approval. In its judgment, the intermediate-term budget planning process was so intimately connected with the general process of estimate revision and consolidation that it could not be carried out effectively by any unit other than the Budget Division of the Ministry of Finance. The specialized knowledge of the latter would be impossible to duplicate elsewhere. On the other hand, the Project Group recommended that the intermediate-term budget planning memoranda of the various ministries be made available, as a matter of course, to the Chancellor's Office. This would increase the flow of information and eliminate duplication of efforts at the individual ministry level.

\section{Expanding the Chancellor's Office}

The Project Group noted that in recent years planning sections had been established in several federal ministries. While these had undoubtedly contributed to the rise of "problem consciousness" in the bureaucracy, their effectiveness had suffered from the organizational polarity between staff and line. The planning sections did not have independent information networks; and the line divisions and subdivisions could not be depended upon to supply the information required. Furthermore, privileged access to the political executive by units without line responsibilities gave rise to frictions.

The planning mechanism of the Chancellor's Office, on the other hand, was regarded as more promising. This is not discussed in detail in the First Report, but some pertinent information has become available recently. ${ }^{42}$ Early in 1967 , the Kiesinger-Brandt Government created a Planning Staff in the Chancellor's Office. This staff was headed by a civil servant of Division Chief (Ministerialdirektor) rank; but its personnel included non-career civil service academic and other experts employed on a contractual basis. Furthermore, the Planning Staff had an advisory council composed of seven professors of various disciplines at German universities; and it had authority to contract for outside policy research and advice. A textbook illustration of the workings of this, in Prussian-German terms, fairly revolutionary planning organism, is the government reorganization project here described. ${ }^{43}$

\footnotetext{
${ }^{2}$ Lompe, Die Rolle von Sachverständigengremien im Prozess der politischen Willensbildung, I6 ZEITSCHRIFT Fü̈R PoLITIK 223, 250-59 (I969).

${ }^{43}$ Böckenförde, supra note 9, at I87-9r, goes so far as to assert the unconstitutionality of the establishment of a political planning staff in the Chancellor's Office. We are reminded of Heinz Wagner's remark that the West German academic constitutional lawyer receives his journeyman's certificate
} 
The Project Group recommended that the policy planning functions of the Chancellor's Office be substantially expanded. It also recommended that these functions be directed by a close associate of the Federal Chancellor of the day who had ready access to the latter, and whose position in the hierarchy of the political Executive was such that he would be accepted as an equal by the cabinet ministers. As for the organization of individual policy planning projects, within-government task forces were deemed most promising. Such task forces were to be composed of members of the ministries concerned and the Chancellor's Office, under the direction of the latter. The federal ministries had the highest level of information in their respective sectors; and "without the intake of this information, but also without knowledge of the sectoral balance of competing social interests achieved by the various ministries, uniform political planning on the Cabinet or Chancellor's level would hardly be possible." ${ }^{\text {"4 }}$

The Brandt Government appears to have accepted these recommendations. For the first time in West Germany, the Chancellor's Office is headed by a cabinet minister. Personnel changes within this office seem to have been particularly rigorous, with apparently full utilization of the power to dismiss political civil servants, and some transfers of career civil servants as well. The current budget authorizes 80 new positions in the Chancellor's Office, bringing its total personnel to over 300 . The Planning Staff, which is now headed by a professor of economics in his middle thirties, has been enlarged in size. Its members participate in top-level policy conferences within the various ministries. There is a budget item for the development of systems analysis in the Chancellor's Office. ${ }^{45}$

On the other hand, this massive increase of the powers of the Chancellor's Office (and, hence, of the Chancellor and his "personal" cabinet minister) has given rise to some resistance. The new Minister of Defense, in particular, is reported to have demanded a binding delimitation, in writing, of the functions of the Minister in charge of the Chancellor's Office; and one of his first acts has been the establishment of a Policy Planning Staff in the Ministry of Defense. It is perhaps significant to note that this latter staff was organized by a well-known, American-educated strategy commenator on temporary six-month leave from the leading West German weekly paper. ${ }^{46}$

upon proving that something is unconstitutional, and becomes a master craftsman upon showing that it cannot even be done by constitutional amendment. Wagner, Um ein neues Verfassungsverständnis, Ig68 DiE ÖFFENTLICHE VERWALTUNG 604, 605.

4 I First Report 201.

¿ See Dre Wert, May 2, I970, at 6; June 22, 1970, at 2 (air mail edition). For a recent detailed account, see Der SPIEGEL, Feb. $x$, I $97 \mathrm{I}$, at $28-38$.

${ }^{10}$ Dr. Theo Sommer of Die Zeit. See DIE WELT, November 3, rg69, at I (air mail edition). The Minister in the Chancellor's Office has also had difficulties in replacing a number of career civil servants in the Chancellor's Office with persons more receptive to the policies of the present Government. For one view of this matter, see Reuter, "... ausserhalb der Legalität"? 20 DeR Deutsche BeAMTE 43 (I970). 


\section{Towards New Departures in Planning Organization}

The Project Group did not regard its recommendations for the expansion of the planning facilities in the Chancellor's Office as a substitute for a more basic restructuring of the political planning process. The expansion recommended would be useful primarily for testing, experimentation, and personnel training purposes; it would not obviate the need for a comprehensive political goal-planning machinery.

In view of its limited mandate, the Project Group did not consider mechanisms such as an Inner Cabinet, which required constitutional amendments for their implementation. Instead, it developed three alternative organizational prototypes against the background of article 65 of the Basic Law, which, as discussed above, bars the creation of a functional disequilibrium between the Chancellor, Cabinet, and Department principles therein laid down. ${ }^{47}$

All three models call for a permanent central Task Force or Working Group for Political Planning. This agency is to be headed by an official of the Chancellor's Office whose position is such as to assure close contact with the Chancellor and the cabinet ministers. The other members of the Task Force are to be the planning officials of the various ministries. Their designation is to depend, from case to case, upon the task at hand.

Political goal decisions are, of course, reserved to the Chancellor and the Cabinet. Program planning decisions, on the other hand, are to be made in the ministries. Each ministry is to have a Planning Board directly subject to the Minister and the State Secretary, but the planning process is to be largely the work of ad hoc task forces at the Division level. These task forces are to include at least one member without line responsibilities, who will serve as his division's representative on the ministry's Planning Board.

As regards personnel, the Project Group deemed political confidence and innovative potential to be of prime importance. It therefore recommended that especially in the higher positions, public servants be assigned planning positions on a nonpermanent basis; and that care be taken, on the Chancellor and Cabinet level, to include officials from all ministries. Significantly, it also recommended that efforts be made to attract experienced personnel from private industry and the universitiespresumably on a short-term basis.

The three alternative prototypes for the central Task Force for Political Planning are, in the main, reflections of different concepts of the optimal balance between the Chancellor, Cabinet, and Department principles governing the organization of the political Executive pursuant to article 65 of the Basic Law. Model I emphasizes the Cabinet principle. The Task Force receives its impulses from its members as instructed by their respective superiors, i.e., the Chancellor and the various Ministers. Draft political programs are submitted to the Cabinet for discussion and general approval, and then routed to the various ministries with instruction to develop

\footnotetext{
${ }^{47}$ See p. 637 supra.
} 
implementation plans. These are checked by the Task Force for compliance with basic policy decisions and for optimal coordination, and submitted by it to the Cabinet for final approval. This latter also serves as the basis for intermediate-term budget planning.

Model II is based on the predominance of the Chancellor principle. It contemplates the establishment of a well-staffed Planning Division in the Chancellor's Office. Planning impulses are transmitted to it by the Chancellor, acting either on his own initiative or in response to suggestions by the Cabinet or individual ministers. Draft political programs received by the Cabinet for initial discussion are thus the product of the Chancellor's Office as instructed by the Chancellor. The Task Force becomes operative only at the penultimate stage of checking and coordinating individual Ministry implementation plans for final approval by the Cabinet. Again, this latter serves as the basis for intermediate-term budget planning.

Model III is a combination of the Chancellor and Cabinet principles. It generally corresponds to Model I, with the difference that both the Chancellor and the Cabinet can give instructions for the initial planning phase to the Task Force, and that the latter has a policy planning staff that corresponds in size to that contemplated by Model II but is organizationally independent of the Chancellor's Office.

At the present writing, the Brandt Government does not appear to have decided in favor of one or the other of these three prototypes. However, the enhanced position of the Chancellor's Office suggests a built-in bias in favor of Model II. There would seem to be some political as well as constitutional objections to this model, which are not entirely dispelled by the First Report of the Project Group and its supporting consultations. ${ }^{48}$ A search for a "non-political" alternative, such as a Planning Office headed by the (large ceremonial) federal President, ${ }^{40}$ seems somewhat quaint. Still, the current West German Federal Government, which has achieved so much by way of government reform in so little time, is not likely to expose itself needlessly to major constitutional criticism when developing its longrange political planning mechanism. While the three organizational prototypes suggested by the Project Group will undoubtedly have some impact, none of them seems currently destined for formal adoption.

\section{III}

\section{The Uses of Comparative Analysis}

Louis Brownlow, it will be recalled, found it "impossible to get any Presidential funds for study abroad."50 The West German Project Group, on the other hand, was quite unencumbered by parochial purse strings. It commissioned no less than

\footnotetext{
${ }^{48}$ See note 30 supre and, for the constitutional problems arising from the separation of powers doctrine, the consultation of Professor Friauf, 2 FrRST REPORT 607.

4This was envisaged by Köble, Wider die Expertokratie, DIE WEIT, November 8, I969, Geistige Welt section, at I (air mail edition).

${ }^{50}$ See p. 626 stspra and note 3 thereat.
} 
seven country studies, two of which deal with the United States and were undertaken there. These studies are reproduced in full in the Appendix of the Report, and their findings are summarized in a special section of the Report itself. ${ }^{51}$ Repeated references, to be discussed further below, indicate a pervasive awareness of foreign institutions and practices.

In the following, an attempt will be made to gauge the significance of these foreign studies, and of the comparative insights based on them, for the work of the Project Group. By focusing on the present author's report on the United States, it is hoped to obtain some insights which might be of interest to American students of government organization. Furthermore, an analysis of "comparative government at work" might furnish some more general insights as to the practical utility of that discipline.

A. "The Constitutional Position and Government Machinery of the President of the United States": Seven Questions and Answers

The foreign country studies are based on a uniform set of seven questions drafted by the Project Group, in some instances augmented by subsequent inquiries on specific points. The seven questions concern (I) the real position of the Chief of Government in the governmental system, especially as regards establishing and enforcing uniform governmental policy; (2) his major instruments for executive leadership, including machinery for policy planning and supervision; (3) the Chief of Government's information system, including the reporting methods of the ministries (departments) as well as information derived from other sources; (4) the real division of power at the summit of the governmental system, especially problems of coordination and methods for their solution; (5) permanent representatives of the Chief of Government, and their competences; (6) parliamentary state secretaries, ministers of state, or ministers without portfolio, and their relations with the regular departments and the bureaucracy; and finally (7) the deficiencies of the present system and efforts at reform. In addition to these standard inquiries, the Project Group also requested information from the present author on problems of coordination between the President's political staff and the federal bureaucracy, and on the current status of the PPB System.

The standard inquiries are clearly inspired by the West German system of government and by the mandate of the Project Group to recommend improvements not requiring constitutional amendment. They are therefore more pertinent to parliamentary government than to a presidential system. Nevertheless, the Bureau of the Budget was mentioned by way of illustration in question 2; there were two country studies on the United States which together take up almost one-third of the space allotted to foreign materials; and the specific inquiries just mentioned indicate a lively interest in the practical workings of the American system.

\footnotetext{
612 FIRST REPORT I-265; I id. at 248-68.
} 
There is hardly any need here to set forth in detail those portions of our study that are descriptive of the formal constitutional system of the United States. Starting with Professor Hermens' felicitous description of the President as "combining the functions of the British Queen and Prime Minister, and absorbing, in his second capacity, the constitutional powers of the entire British cabinet, ${ }^{352}$ it is pointed out that the constitutional problems posed by article 65 of the Basic Law ${ }^{53}$ simply do not exist in the United States. The real constitutional problem is coordination between the President and Congress, not coordination within the Executive. The limitations imposed upon Executive leadership by the separation of executive and legislative powers is illustrated by fairly detailed references to government reorganization, the appointment power, legislation and budgetary matters, and control over independent regulatory commissions. Not much time is spent on the problems referred to in questions 5 and 6, relating to permanent representatives of the President and executive representation in Congress; the personalized unitary executive principle inhibits the former and the incompatibility rule obstructs the latter. Nevertheless, it is pointed out that in recent years, there has been an amazing extension, both by statute and by executive order, of the functions of the Vice President-a development that has since continued. ${ }^{54}$ Furthermore, mention is made that the constitutional prohibition of membership in Congress by persons "holding any office under the United States" has not prevented the occasional use of Senators and Congressmen on diplomatic missions, nor even the formal codification of that practice in the United Nations Participation Act of $1945^{.55}$

Like so many other things, it is observed, such practices and even institutional mechanisms are entirely dependent upon their political and practical attractiveness for the current incumbent of the White House. This reflects the cardinal conclusion of the study, made in the context of information networks (question 2) but

\footnotetext{
${ }^{63}$ F. Heraiens, The Representative Republic 464 (I958).

${ }^{63}$ See p. 637 supra.

os At the time of the preparation of our study for the First Report, the Vice President was a member of the National Security Council; the chairman of the National Aeronautics and Space Council and of the National Council on Marine Resources and Engineering Development; the alternate chairman of the Council for Urban Affairs, the Cabinet Committee on Economic Policy, and the Council on Environmental Quality; the Office of Intergovernmental Relations was under his immediate supervision. 50 U.S.C. $\$ 402$ (Supp. 1970); 42 U.S.C. $\$ 247$ (Supp. I970); 33 U.S.C. $\S$ rro2 (Supp. 1970); 3 C.F.R. 102, $103,122,105$ (1969). In the meantime, the former Council on Environmental Quality has been transformed into a Cabinet Committee, of which the Vice President is again the alternate chairman, 35 Fed. Reg. 4247 ( 9970 ). He has also been made the alternate chairman of the Council for Rural Affairs, 3 C.F.R. 206 (1969); and, perhaps most importantly, he is a member of the Domestic Council established pursuant to Reorganization Plan No. 2 of I97o. For historical background, see David, The Vice Presidency: Its Institutional Evolution and Contemporary Status, 29 J. Polirrcs 72I (1967).

${ }^{5 t} 22$ U.S.C. $\$ 287(\mathrm{Ig} 64)$. Literature on this arrangement is quite sparse. See A. BEICHMAN, THE "Other State Department." The Untted States Mission to the United Nations--Its Role in the Maring of Foreign Policy I94-96 (1968); and, for the dilemma posed by conflicting loyalties, Sen. Vandenberg's letter of January 9, 1947, to Mrs. Roosevelt, A. Vandenderg, The Private Papers of SENator VANDENBERg 330-3I (A. Vandenberg, Jr., ed. I952).
} 
also applicable to other questions, including coordination (question 4). The authority "to require the opinion, in writing, of the principal officer in each of the executive departments," conferred upon the President by article II, section 2, of the Constitution, it is stated,

has apparently never been seriously considered, in the United States, as an institutionalization of informatory and advisory authority. Quite the contrary, the prevailing view appears to be that a statutory channelling of the President's sources of information would be unconstitutional. The view expressed in (West Germany) that political advice to the government is a public function and hence is subject to limitations imposed by constitutional law, appears strange to American constitutional thought. Thus, every President informs himself from whatever source and by whatever procedures he deems appropriate. ${ }^{50}$

This passage was to find its way into the report of the Project Group. ${ }^{\text {t7 }}$

Just as there is little purpose to be served by repeating here our observations on the formal constitutional position of the American federal executive, there is almost equally small need for a repetition of the rather extensive descriptions of Presidential information networks and coordination mechanisms. To a large extent, these are based on quite familiar publications and on a few interviews conducted within the academic and research communities; contributors to the present symposium are prominently represented under both headings. ${ }^{58}$ On the purely descriptive level, there is hardly any claim of originality-except, perhaps, for the discovery that entries under "Management Consultants" in the Washington yellow pages yield a good bit of otherwise quite elusive information about federal policy contract research, including the gem, in at least one advertisement, "Governments Only."

Evaluation of American institutions and practices with a view to their suitability to West German conditions is likely to be of more interest here. The Project Group had not, in terms, called for such an evaluation by its consultants in charge of country studies. However, it quite understandably expressed an interest in information as to the defects of foreign systems in actual experience, as indicated especially by question 7 (deficiencies of the present system and efforts at reform). After all, it is greatly preferable, for governments as well, to learn from the failures of others.

This frame of reference necessarily gives our recommendations and conclusions

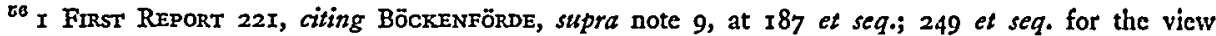
expressed by some authorities in West Germany (see also note 43 supra); and Bundy, Houv Foreign Policy is Made-Logic and Experience, 30 U. PITT. L. Rev. 437, 44I (1969), for the prevailing American position.

57 I FrRst REPORT 254.

${ }^{68}$ Our study acknowledges invaluable assistance from Professors Thomas E. Cronin and Norman Thomas; Allen Schick gave of his time to introduce us into the mysteries of PPBS. 2 Finst REPoRT $2 \times 2$. Professor Harvey C. Mansfield's then unpublished paper on federal executive reorganization, presented originally at the 1968 annual meeting of the American Political Science Association, furnished most of the information for our discussion of government reorganization; see 2 FIRST RePorT, 213-15, 258 n.I4. Mansfield, Federal Executive Reorganization: Thirty Years of Experience, 29 Puв. AD. Rev. 332 (1969).
} 
a somewhat negative bias. It is hoped, however, that what was said in that connection, and what will be repeated below, will not be taken as implying any personal dissatisfaction with an exceptionally generous and pleasant host country.

The American system of government appears to have two built-in dysfunctional elements of constitutional magnitude. First, the President has only limited, and frequently insufficient, means for the legislative and budgetary implementation of his program. Secondly-and somewhat paradoxically-his responsibilities within the executive department, encompassing the totality of the functions of Queen, prime minister, and cabinet, are dangerously close to requiring superhuman talents and energy.

It is believed that these structural weaknesses are not outweighed by the advantages of a uniform personalized executive with stable tenure for a period of years. In any event, the very history of government reorganization on the federal level is strong evidence that there are serious and persistent problems of government efficiency in a presidential system. It was concluded, therefore, that the adoption of such a system would not, by itself, offer substantial advantages to a country with a functioning system of responsible cabinet government. This conclusion is again echoed in the Project Group report. It seems to receive added weight from the amazingly swift and comprehensive implementation of the recommendations of that report, especially if contrasted with the markedly different experiences of the Brownlow Committee. ${ }^{59}$

On the other hand, the United States has had, for some time, the most vital and productive economic system in the world. Furthermore, its social system, while not quite as open and egalitarian as sometimes claimed, is still in marked contrast to West Germany's "two societies," or "halbierte Gesellschaft" so eloquently described and decried by Professor Dahrendorf. ${ }^{60}$ It seems reasonable to assume that the exceptionally high degree of receptivity and adaptability of the American federal executive is, in good measure, causally interrelated with the dynamism of the American economy and the openness of American society. If this assumption is accepted, the three phenomena of American federal government singled out as particularly startling to orderly minds trained in the German civil service tradition are highly likely to be prized assets rather than curious liabilities. These are (x) the massive uncertainties and manifest neglect of organizational constitutional law; (2) the heterogeneous origins, short tenures, and hence, seemingly somewhat amateur character of the top ranks of the federal political executive; and (3) the inclination to farm out to non-governmental organisms, on a contract basis, the formulation of federal public policy.

\footnotetext{
${ }^{80}$ See p. 632 supra; BrownLow, supra note 3, at 383-402, 413-22; and especially R. POLENBERG, REorganizing Roosevelt's GovernMient. The Controversy Over Executtve Reorganization i936-r939 (I966).

${ }^{\circ 0}$ R. Dahrendorf, Geseltschaft und Demookratie in Deutschrand 301 (rg68). Professor Dahrendorf's own translation, Society and Democracy in Germany 273 (1967), uses the term, "divided socicty."
} 


\section{r. Organizational Constitutional Law}

The neglect of organizational constitutional law in the United States is, prima facie, nothing short of scandalous. Again and again in interviews and conversations with knowledgable persons in and out of government, we heard the complaint that "nobody teaches you how the government is run." Standard books of instruction on constitutional law used at American law schools, even if called "Cases and Materials," proved to be literally without the slightest guidance for our study. As Professor William W. Van Alstyne demonstrated by a postcard poll of teachers of constitutional law at American universities, this neglect of the subject is rather firmly rooted in lack of basic knowledge. ${ }^{61}$ Monographic legal literature on organizational constitutional law is almost totally lacking. ${ }^{62}$

It might be contended that this neglect is merely the result of a division of labor, traditional at least since the epic Burgess-Dwight confrontation at Columbia University, ${ }^{63}$ between litigation-oriented law schools and institution-oriented departments of political science, and that, in any event, the rather remarkable expansion of the concept of justiciability in recent years ${ }^{64}$ is likely to kindle the interest of professional lawyers in constitutional questions not previously capable of judicial resolution. However, this would presuppose, at least until the total eclipse of the political-questions doctrine and the disappearance of all obstacles to justiciability grounded on the cases-and-controversies doctrine and on standing, that political scientists are carrying on the traditions of Burgess, Willoughby, and, perhaps, Corwin. ${ }^{65}$

${ }^{61}$ Letter to the Editor, N.Y. Times, Apr. 8, 1965, at 38, col. 3 (Late City Edition):

"In a mail poll I submitted [four] questions . . . based on the Twelfth Amendment to the Constitution, to all professors currently teaching constitutional law in American law schools. Each was asked to respond impromptu, without looking up the answers in advance.

"Ninety-six responses to each of the four questions were received. Over-all, 70 per cent of the answers submitted were technically incorrect. Specifically, 62 per cent, 82 per cent, 66 per cent and 69 per cent of the answers submitted to the first through the fourth question, respectively, were incorrect."

${ }^{62}$ By way of contrast, see Professor Dagtoglou's Comment, [1969] PuB. L. IOI-111, which revicws over 50 West German monographs on constitutional law published in 1968 . Cf. his Comment, [1970] id. at $3 \times 7-29$, which lists a somewhat lesser number for 1969 .

${ }^{63}$ J. Goeber et al., A History of THE School of Law, Columbia University ch. 4 (1955); J. Burgess, Reminiscences of an American Scholar, The Beginnings of Columbia University, ch. 6 (I934).

a4 Baker v. Carr, 369 U.S. I86 (rg62); Flast v. Cohen, 392 U.S. 83 (1968); Powell v. McCormack, 395 U.S. 486 (1969); and, after our study was completed, Association of Data Service Org., Inc. v. Camp, 396 U.S. 150 (I970); Barlow v. Collins, 396 U.S. I59 (1970).

of A. Somit \& J. Tanenhaus, The Development of American Political Science: From Bunoess to Behavioralism r8-ig (ig67); J. Burgess, Political Science and Constitutional Law (I890); W. Willoughay, The Constitutional Law of the United States (2d ed., t929). E. S. Corwin would seem to be more correctly classified as a political and constitutional historian, see, e.g., E. Corwis, THe President, Office and Powers 1787-1957 (4th rev. ed. 1957), and as an outstanding "case law". oriented constitutional lawyer, as witness his perennial, The Constitution and What it Means Today (12th ed. 1958) and his monumental The Constitution of the United States Annotated, AnalYSIS AND INTERPRETATION (x953). He does not appear to have been much persuaded by the one attempt to set forth American constitutional conventions in the British understanding of that term, which significantly was undertaken by a British author writing in England. H. Horwul, The Usıaes of the American Constitution (I925); Corwin, Book Review, 20 AM. Pol. Sct. Rev. 436 (Ig26). 
Manifestly, that has not been the case. We might speculate on the causes, and especially on the relative weight to be attributed to the scramble for a slice in the lucrative market made up by an estimated one million captive buyers per annum of assigned textbooks on American Government; the two-step process of professional legal education which stamps much of political science instruction as undergraduate and "pre-legal" (perversely adding incentive to the emulation of law teaching at a "lower" academic level); and the general decline of public law as a prestigious discipline in increasingly behavior-oriented political science departments. ${ }^{66}$ On purely intellectual grounds, the reason suggested last seems to be the only one intrinsically worthy of respect. Still, it is acceptable only to the extent that the behavioral approach faithfully reflects the reality of organizational constitutional law in the United States.

This depends, quite simply, on whether American organizational constitutional law is dominated by political behavior or governed by constitutional convention. The answer is not necessarily foreclosed by the predilection of common-law trained minds for judicially enforceable rights; the British constitution and its overseas transplants illustrate that a common law system is indeed eminently capable of generating the opinio necessitatis iuris which distinguishes constitutional convention from politically convenient custom. ${ }^{67}$ However, it is quite useless to pursue this question further with regard to the United States. Here, political behavior not subject to judicial sanction is manifestly treated as free from legal restraint. The prevalence of the "bad man" theory of the law ${ }^{68}$ on the constitutional level even extends to the interpretation of constitutional provisions that are not, or not as yet, subject to judicial scrutiny.

To mention some examples: When testifying before the Jackson Committee, Governor Nelson Rockefeller asserted that the Vice President was a member of the Legislative department by virtue of his constitutional position as president of the Senate, and could therefore not be delegated executive functions in view of the

${ }^{\circ 0}$ As to the decline of public law as a prestigious discipline, see Somit \& Tanenhaus, Trends in American Political Science: Some Analytical Notes, 57 AM. Por. Scr. Rev. 933, 940-4I with tables IVVI (1963). Schubert, Behavioral Research in Public Law, 57 AM. Por. Scr. Rev. 433, 445 (Ig63), speaks of "the long period during which public law was an exotic bayou, cut off from the mainstream of theoretical and methodological advances in political science." Whether or not behaviorism has come to the rescue as there predicted is immaterial for present purposes, since judicial behaviorism comes rather close to being the exact antidote to any threat of the revival of interest in organizational constitutional law on the part of political scientists. Cf. Verney, The Education of a Political Scientist, 3 Can. J. Pol. Scr. 345, 352 (1970): "Presidential government ... has succeeded in the United States but has never been successfully adopted by other countries. (Perhaps this explains why American students of comparative politics have ignored traditional governmental institutions, which indicate the uniqueness of the United States, and have concentrated on the political process where Americans behave, or are thought to behave, like people elsewhere.)"

${ }^{07}$ See A. Dicey, Introduction to THE Study of the LAw OF THE CONSTitution, ch. I4-15 (ioth ed. 1959); I. Jennings, The Law of the Constirution, ch. 3 (5th ed. I959); J. Mitchell, Con* strtutionat. LAw 26-39 (2d ed. I968); British Coal Corporation v. The King, [I935] A.C. 500, 5 II (P.C.); Madzimbamuto v. Lardner-Burke, [1968] 3 All E.R. 56r, 573 (P.C.) Cf. Adegbenro v. Akintola, [1963] A.C. $6 \mathrm{r}_{4}, 63 \mathrm{r}-32$ (P.C.).

${ }^{08}$ First set forth in Holmes, The Path of the Law, Io HaRv. L. Rev. 457, 459 (1887). 
incompatibility rule. ${ }^{69}$ (The real reason for the sparing use of the Vice President in the Executive department is not this quaint construction of the vice presidency as a Legislative estate with an Executive remainder, but rather the fact that the President has no control over the Vice President's term of office. ${ }^{70}$ ) The constitutional locus of the reorganization power is largely unsettled. The prevalent practice under the Reorganization Acts of executive reorganization by presidential plan subject to congressional veto is open to grave constitutional objections. The "congressional veto" was, in fact, deemed unconstitutional by President Roosevelt."

The current Reorganization Act, in keeping with the somewhat wavering tradition established by the Reorganization Act of 1939, requires an act of Congress for the creation, abolition, or complete merger of government departments. Their principal officers are, collectively, a constitutional organ by virtue of the Twenty-fifth Amendment; and their appointments are subject to approval by the Senate. Yet, nothing seems to prevent the President from conferring personal cabinet rank, without the necessity of Senate approval, on members of the White House staff. ${ }^{72}$

More recent examples would include the assertion of a presidential prerogative in the appointment of Supreme Court justices that is clearly contrary to historical precedent. ${ }^{73}$ At the other extreme, we find a veto message described as containing

${ }^{69}$ H. Jackson, JR., The Natjonal Security Council-Jackson Subcommittee Papers on PolicyMaking at the Prestdential Level i79 (I965) (testimony of July $x$, I960).

70 This point is generally regarded as settled by former President Hoover's testimony of January 16 , 1956. Hearings on the Administrative Vice President Before the Subcomm. on Reorganization of the Senate Comm. on Government Operations, 84th Cong., 2d Sess. 13-14 (1956) (testimony of Mr. Hoover).

${ }^{71}$ Jackson, A Presidential Legal Opinion, 66 Harv. L. Rev. 1353 (1953). See generally Ginnane, The Control of Federal Administration by Congressional Resolutions and Committees, 66 HARv. L. REv. 569 (1953). For an excellent brief discussion of the reorganization power which had previously escaped our notice, see J. Kallenbach, The American Chief Executive. The Presidency and the Governorship 380-87 (1966).

${ }^{2}$ Dr. Arthur Burns received this rank in January, I969; that seems to have set a precedent for the top White House Office officials of the Nixon Administration.

${ }^{73}$ In a letter of March 31, r970 to Senator William B. Saxbe of Ohio concerning his (ultimately unsuccessful) nomination of Judge G. Harrold Carswell to the U.S. Supreme Court, President Nixon stated:

"What is centrally at issue in this nomination is the constitutional responsibility of the President to appoint members of the Court-and whether this responsibility can be frustrated by those who wish to substitute their own philosophy or their own subjective judgment for that of the one person entrusted by the Constitution with the power of appointment. . . .

"[U]nder the Constitution it is the duty of the President to appoint and of the Scnate to advise and consent. But if the Senate attempts to substitute its judgment as to who should be appointed, the traditional constitutional balance is in jeopardy and the duty of the President under the Constitution impaired."

I16 Cong. Rec. S4937 (daily ed. April 2, 1970).

The assertion that the President is "the one person entrusted by the Constitution with the power of appointment" (emphasis supplied) is contrary to the wording of the Constitution, which provides, in article $2, \$ 2$, I , that the President "shall nominate, and by and with the advice and consent of the Senate, shall appoint . . . judges of the supreme court. . . (emphasis supplied). The letter quoted above is said to be in large part the work of Charles Colson, the President's legal adviser, who has been quoted as saying, "The legal brief we prepared on this used the word 'nominate' all the way through, but it came out "appoint' in the letter." NEwsweEs, April 13, 1970, at 15. Surcly, state papers deserve more discriminating attention. Quite apart from this, however, the cardinal contention that the Senate may not substitute its own philosophy or its own subjective judgment for that of the President in 
a "political-science lecture on Presidential prerogatives" in point as if there could be the slightest doubt about his legal entitlement to veto federal enactments at will. ${ }^{74}$

\section{Personal Mobility of the Political Executive}

American observers are likely to be troubled more by the current scholarly neglect of organizational constitutional law than by its actual state. They would tend to regard massive ambiguity and uncertainty in this area as, on balance, a positive factor, since the absence of clear rules prevents the ossification of traditional structures by constitutional mandate. However, they are likely to be somewhat less complacent about the selection and tenure of the political Executive below cabinet level. There are roughly I25 government officials in the ranks of Secretary to Assistant Secretary, and in corresponding positions with different nomenclatures. A Secretary can be expected to have a tenure of about three years; the average tenure of Assistant Secretaries, on the other hand, is likely to be around two years. It is generally estimated that the first year in office is largely spent on what might be called on-the-job training. ${ }^{75}$

Small wonder, then, that in Ig6o, the Senate at the request of the Jackson Committee on National Policy Machinery adopted a resolution expressing

the sense of the Senate that individuals appointed to administrative and policymaking posts should be willing to serve for a period long enough to permit them to contribute effectively in their assigned tasks $\ldots{ }^{76}$

As the Brookings studies have shown, the record is not quite so bleak. The average public service record of the political executive at the time of initial subcabinet level appointment is five years; and there is a substantial flow of appointments from within political and professional civil service ranks of the various departments. On the other hand, the recruiting process is hardly likely to inspire confidence in the professional soundness of the appointments made. The appointment of a specially qualified Assistant Secretary pursuant to the recommendation of an equally qualified Secretary might not be a mere chance event, but it is plainly rather exceptional. ${ }^{77}$

The disadvantages of this top-level spoils system with payoffs in social prestige or public service satisfaction are substantial. Besides the obvious drawbacks of amateur administration as such, there is above all the lack of confidence of the top levels of

judicial appointment matters is contrary to historical precedent and the overwhelming weight of the informed opinion. See, e.g., Kallenbacr, supra note 7I, at 393. Cf. Black, A Note on Senatorial Consideration of Supreme Court Appointees, 79 YALE L.J. 657 (1970), which quite unintentionally underscores our remarks above.

"Semple, Jr., The Middle American Who Edits Ideas for Nixon, N.Y. Times Magazine, Apr. 12, I 970 at 32,69 .

${ }^{70}$ See generally D. Stanley, D. Mann \& J. Doig, Men Who Govern-A Biographicas Profile of Federal Polittcal Executtves ( 1967 ); D. ManN and J. Doig, The Assistant Secretaries (ig65); Mann, The Selection of Federal Political Executives, 58 Am. PoL. Scr. Rev. 8x (1964).

${ }^{70}$ S. Res. 338, 86th Cong., 2 d Sess., I06 CoNG. REc. I5705 (I960).

${ }^{77}$ See STANLEY, supra note 75 , at $4 \mathrm{I}$, and generally Mann, supra note 75 . 
the professional civil service in departmental leadership, and a consequent strengthening of the Bureau-Congress-clients triangle which obstructs the implementation of presidential policy. ${ }^{78}$ On the other hand, it is difficult to envisage a system that is more conducive to the rapid exchange of ideas and information between government, industry, and the academic community.

\section{Government Policy Formulation by Research Contract}

The Executive Office of the President owes its existence to the recommendations of the Brownlow Committee; the PPB System is a creation of the RAND Corporation. These two standard examples serve to demonstrate the significance of contract research for the formulation of public policy in the United States. However, they may be likened to the tips of otherwise rather unexplored icebergs. "Hard" information about federal contract research on government policy, as contradistinguished from science and technology, ${ }^{79}$ is not so readily obtainable.

We know that the sixteen Contract Research Centers of the Defense Department at one time employed a total of 346 social scientists (enough to staff the departments of economics, political science, and sociology of at least three universities), and that the Department spent about $\$ 30$ million a year on policy research contracts. ${ }^{80}$ This figure is in marked contrast to the $\$ 5$ million budget of the Bureau of Intelligence and Research in the State Department. ${ }^{81}$

Critics have called attention to the possibility of conflict between the policy planning operations of the State and Defense Departments, to the "hawkish" bias of the latter's principal consultants, and to errors in judgment in the formulation of projects and the choice of contractors. The classic example of the latter is the "Pax Americana" project, which charged the Douglas Aircraft Corporation with the task of projecting the world political situation in $1985 .{ }^{82}$ Seemingly, a somewhat more short-range analysis of the economic future of Douglas Aircraft would have been more appropriate.

\footnotetext{
${ }^{78}$ See Brown, The President and the Bureaus: Time for a Renewal of Relationships? 26 Pun. AD. REv. I74 (I966).

70 C. Danhof, Governaent Contracting and Technological Chunge (ig68); M. Reagan, Sctence and the Federal Patron (ig69). G. Lyons, The Uneasy Partnership-Soctal Sctence and the Federal, Government in the Twentieth Century (I969), a veritable goldmine of information, appeared after the conclusion of our study.

${ }^{80}$ For details, see Hearings on Defense Department Sponsored Foreign Affairs Research Before the Senate Comm. on Foreign Relations, 9oth Cong., 2d Sess. (I968).

81 Platig, Research and Analysis, 380 THE Annass 50, 56 (I968). For the origins of this disparity, see D. Acheson, Present at the Creation, ch. I8 (I969); and for the reorganization of State Department research activities since our study, 6r Dep'T STATE BuLL. 74 (1969).

82 Green, Science, Government and the Case of Rand, A Singular Pluralism, 20 Wonu.d Pourrics 301 (I968); Kaufman, As Eisenhower Was Saying . . "We Must Guard Against Univarranied Influence By the Military-Industrial Complex," N.Y. Times Magazine, June 22, 1969, at ro; Rice, The Cold-War College Think Tanks, Washngton MonrmLy, July, 1969, at 22. Quite another question, and a somewhat neglected one, is the effect of such contract research on the universities. Cf. Jaffe, Professors and Judges as Advisors to Government: Reflections on the Roosevelt-Frankfurter Relationship, 83 Hurv. L. REv. 366, 368-73 (1969).
} 
It should be recalled, however, that we are dealing with a subject that is discreet but not discrete. Federal contract research on policy questions is pervasive but not centralized; and failures and conflicts, being more newsworthy, have greater surfacing power. The advantages of seeking guidance for decisions involving federal public policy by contract research seem obvious. These offer almost unlimited flexibility in the choice of informants; ready access to the most current levels of insight of the academic and research communities; and savings, both in funds and in maneuverability, by the avoidance of the alternative solution of creating ad hoc bureaucracies for policy problems as they arise.

On the other hand, a traditional view of responsible government would require that public policy be formulated by politically and legally accountable officials and public servants. While such ultimate responsibility is not necessarily waived by the contractual procurement of policy ideas and programs, there seems little doubt that this practice does, in fact, shift public decisions to a non- or pre-public sphere. That is especially the case where the progress of the study commissioned has already led to a crystallizing of informed opinion, or where as yet unresearched possibilities are obscured by carefully elaborated alternative recommendations.

\section{Summary: State and Society in the United States and West Germany}

Our conclusion was that the lack of clarity in organizational constitutional law, the remarkably high mobility of a heterogeneous political executive, and the extensive use of contract research were phenomena of a political system that did not recognize a significant distinction between "state" and "society." As already mentioned, these factors were deemed crucial for a highly receptive and adaptable political leadership system, and at the same time causally interconnected with an open society and a vital economy.

Implicitly accepting Professor Dahrendorf's trenchant critique of West Germany as a "halbierte Gesellschaft" managed by a law-trained "service class" quite unreceptive to the needs and aspirations of the "lower" half of the population ${ }^{83}$ we posed the question whether a radical reduotion of the influence of the German service class was not in order. This could be achieved, it was suggested, by a substantial increase in the number of political officials and, possibly, the massive use of contract research on policy questions.

Such a course of action would be likely to decrease the significance of the Rule of Law in organizational constitutional law. Indeed, greater flexibility in this area might even be the pre-condition for the creative activity of a broad and dynamic political leadership group co-opted by constant interchange with the universities

\footnotetext{
${ }^{83}$ Darrendorf, supta note 60, to6 et seq. of the German and 94 et seq. of the English editions. Note, incidentally, the recently declining prestige of lawyers in West German society, discussed by W. Kaupen, Dre Hüter von Recht und Ordnung. Die soziale Hierkunft, Erziehung und Ausbitduno DER DEUTSCHEN JURISTEN (Ig69), and by Rasehorn, Juristen auf dem soziologischen Prïfstand, [r9jo] NeUe JuRIstiche WOChENSCHRIFT 24.
} 
and the economy. But would West German society still respect a State that had so drastically opened itself to the people?

A somewhat different question was whether the added costs of such drastic reforms were worthwhile. As one of the two super-powers in a still basically bipolar world, the United States necessarily had to aspire to a position of leadership in all fields of significance. States with more modest means simply could not attempt to operate on the same scale.

This was not to say, we concluded, that the American example was, but for some technical details, only of anecdotal or antidotal interest for West German government and administrative reformers. The point was, rather, to draw attention to the possible consequences of the reception of those constitutional and administrative institutions of the United States which were substantially shaped by the American social system and a specific "American way of life." There will be occasion to return to these remarks further below. ${ }^{84}$

\section{B. Foreign Materials in the Report}

As already indicated, several references to foreign systems of government found their way into the Project Group Report. In the following, these references will be mentioned as they occur. It is hoped that this will afford some insights into the practical value of comparative government which might outweigh the tedium of recital by rote.

The first part of the Report, dealing with the delimitation of the spheres of competence of the federal ministries, contains about half a dozen such references. At the outset, it is pointed out that here, foreign experiences were found to be helpful only as to some details. These latter would appear to include the following: First, on the issue of special-purpose ministries, the French experience with its tendency toward the "technocratization" of political leadership is invoked to buttress a negative recommendation. Second, the rejection of the "optimal" small group figure of seven or nine as a criterion of cabinet size is reinforced by reference to British and French experience, although "in view of differences in constitutional structure, such comparisons with foreign countries ... do not afford an even approximately reliable standard." This is followed by a rejection of the Inner Cabinet device as not only

\footnotetext{
${ }^{84}$ See p. 664 infra. For a striking parallel, see Ridley, French Technocracy and Comparative Government, 14 Political Studies 34, 52 (rg66):

"Technocratic leadership depends on the French educational system and on the general structure of careers. We could not early copy French administrative or managerial instiutions, even if we should want to, because we live in a different society with a different culture. That is only saying, of course, what is often said by those who argue that we need to reform our own educational and recruitment systems if we are to modernize Britain. Even this, however, would not necessarily give us anything like the French technocracy. British technocrats would not automatically develop the same sense of responsibility that flows from the French notion of the positive state. One cannot so easily acquire a tradition that has been built up over centuries. We are back at the starting point. What practical lesson can one in fact learn from comparative studies?"

For some tentative answers to that question, see p. $66_{3}$ infra.
} 
beyond the mandate of the Project Group because it would require constitutional amendment, but also as reportedly unsuitable for German constitutional life.

Third, the creation of a Ministry for Coordination was not recommended because domestic and foreign experience showed the futility of coordination especially of fundamental views on the same level. Fourth, on the positive side, cabinet status for the Post Office was justified, inter alia, by similar status in other countries. Finally, in reiteration of previous comments on coordination between equals, British as well as West German experience is invoked in support of the proposition that a minister without porffolio might be more effectively used for primary political tasks than as a coordinator at the cabinet level, as he was hardly likely to be successful in the latter task. ${ }^{85}$

The section on parliamentary state secretaries, ministers of state, and ministers without portfolio apparently does not contain a single mention of foreign materials. On the other hand, some key references thereto are to be found in the third and last part of the report, relating to the improvement of the machinery of the Federal Chancellor and Government. The conclusions drawn from the foreign country and West German state studies are summarized as follows:

The problems found to exist in the machinery of the [West German] federal government are to be encountered, to a lesser or greater extent, in all foreign countries covered by this inquiry. They are equally present in the government machinery of the [West German] states.

Certain peculiarities are essentially the products of historical developments.

The constitutional position of government institutions is only of minor significance in relation to existing inadequacies. Comparable deficiencies are found in the Presidential, Cabinet, and Chancellor systems. Therefore, none of the problems could be solved merely by, for instance, introducing the Presidential system in the Federal Republic.

All of these systems of government have, in addition to conventional tasks, met with new problems that make it necessary to further develop the traditional system. ${ }^{86}$

There also is a reference to the PPB System which is found to be less effective than the West German system of intermediate-term budget planning; and to British thought on the reduction of cabinet size, the French Planning Office, and the Swedish system of executive government (the latter had not been the subject of a special study ${ }^{87}$ ).

By far the most detailed and frequent mentions of foreign materials are to be found in the two appendices to Part III of the Report. The first, which is a methodological survey entitled "Basic Remarks on the Process of Political Decision," contains the following observation:

The organization of professional advice in the governmental system requires detailed studies, which the Project Group has only been able to initiate in the few

\footnotetext{
${ }^{85}$ I FIRST REPORT 7, IO, II, I2, 21, 24.

${ }^{86} \mathrm{Id}$. at $\mathrm{I} 90$.

${ }^{87}$ Id. at I92, 205.
} 
months of its activities. Here, it will be especially necessary to have recourse to the manifold experiences in France, England, and the United States, in order to utilize further sources for the critical evaluation of our own system. ${ }^{88}$

The Project Group then singled out for special mention some methods of political planning developed in recent years in the United States. Here, it was able to rely on a particularly thorough report on "Political Planning," prepared for the Project Group under the direction of Professor Oberndörfer. The planning techniques referred to include the Delphi Method, systems analysis, cost-benefit analysis, relevance procedure, operations research, PPBS, network planning, and electronic data processing. Discussion is mainly descriptive, but in connection with PPBS, it is stated:

In view of political and constitutional conditions that differ from those of the United States, and the (in some respects) already further developed budgetary process of the Federal Republic, the PPBS cannot simply be adopted by German administration. Nevertheless, the focal points of the system . . . are of significance for German planning processes as well. ${ }^{89}$

The second appendix to Part III of the Report contains summaries, by the Project Group, of the studies on Great Britain, the United States, France, Italy, Austria, Switzerland, and the West German states. Except for these latter, all references, of course, are to foreign institutions. Nevertheless, occasional comparisons with West German conditions, and especially selections of subjects for further study, supply some evidence as to the practical value of the comparative approach in the judgment of the Project Group.

There are two such references to Great Britain, both of them of the former variant. First, British opinion as to the ineffectiveness of a twenty-member cabinet as a working group for the development of policy guidelines is related to a similar judgment prevailing in West Germany. Secondly, and more significantly, the process of information circulation within the political system is described as working "much better" in Great Britain than it does in West Germany. This is traced to the central organization of public administration. There are also some remarks, not expressly comparative, as to the lack of a need for legal norms on coordination of government activities. Such rules have not been necessary in the past, in the judgment of the Project Group, in view of the prevalence of a basic political and social attitude characterized by a desire to cooperate and a willingness to compromise. Furthermore, attention is called to the inhibitions of British civil servants against

\footnotetext{
${ }^{83}$ Id. at 238 -39.

${ }^{80}$ Id. at 240-245. The Oberndörfer study, entitled "Political Planning," will be found in $2 i d$. at 3r3459. More recently, a higher civil servant has expressed the opinion that while West Germany has an exemplary legal framework for fiscal planning, the United States has furnished the exemplary methods and techniques for modern intermediate-term fiscal planning. Mennel, Mehrjährige Finanzplanung im Ausland, 29 Finanzarchiv 75, 88 (1970). But see Brümmerhoff, Das "Planning-Programming-Budgeting System," id. at 64,74 .
} 
political activity, which is said to be rooted in English mentality. ${ }^{30}$ It seems reasonable to see some traces of implied self-criticism in this passage.

With respect to the United States, there is little attempt at comparison, save for a reference to the obvious difference between the presidential system and the unique combination of the Chancellor, Cabinet, and Department systems in West Germany in article 65 of the Basic Law. ${ }^{91}$ However, no less than three areas are singled out for further study. First, the Project Group notes a trend toward the evolution of the Executive Office of the President, and more particularly of the White House staff, into a de facto presidential cabinet with a position superior to that of the federal cabinet. Its interest in additional research of this development is probably traceable to apprehensions about the constitutional implications of the creation of a planning staff in the Chancellor's Office. ${ }^{92}$

Secondly, the Project Group expresses interest in the non-fiscal activities of the Bureau of the Budget, especially as regards planning, coordination, direction, and control of government activity. Finally, it singles out for detailed future attention what is termed the "expansion of planning horizons" through the use of presidential advisory committees and of contract research, especially to the extent that the latter "impinges upon political goal planning and has for this reason met with special scepticism." ${ }^{\text {"3 }}$

The French system of government is described in somewhat greater detail in the Report than is the American, but interest in it seems substantially more limited. The Project Group is understandably interested in the working of the Commissariat Général du Plan, and expresses an intention to seek more information both as to the type of plan elaborated (i.e., whether it is unilinear or alternative), and as to the planning methods and techniques employed by the French General Planning Commission, with a view to determining their suitability for West Germany. Other than that, it merely notes that the extensive employment of special staffs by French cabinet ministers has kept the category of political public servants relatively small as compared to West Germany. ${ }^{94}$

Interest in Italy is minimal:

In judging the capacity of the system for political planning, the short tenures in office of the governments will have to be considered. This circumstance hardly permits comparisons with the Federal Republic, especially as regards political goal definition..$^{9 \overline{5}}$

A similar lack of interest is manifested in Austria, because the unanimity rule for cabinet decisions, as contrasted with the vital position of the Chancellor under

\footnotetext{
${ }^{\circ 0}$ I FIRST REPORT, supra note 5, at 250, $25 \mathrm{I}$.

${ }^{01} \mathrm{Id}$. at 253. See p. 637 supra.

D2 I FIRST REPORT B53-54; see p. 647 supra.

${ }^{03}$ I First RePoRt 254, 255. Cf. Jaffe, supra note 82.

od I First Report 259, 260.

of Id. at 262 .
} 
the West German system, has inhibited the development of central planning institutions. ${ }^{96}$ As regards Switzerland, the Project Group limits itself to noting what is termed the most advanced level of government reform thinking of all countries studied, and the "almost complete" identity of Swiss and West German criticism of the respective systems of government. ${ }^{97}$

Rather expectedly, such similarities are also observed with respect to the West German state governments studied. Here, the Hamburg "Planning Triangle" is singled out for special attention. ${ }^{98}$ It should be noted that the superb report on German state governments made under the direction of Professor Fritz Scharpf also included substantial amounts of confidential information which were omitted from the published version. ${ }^{99}$

In its introduction to the appendix volume, the Project Group mentioned the need for further studies on the United States, France, Great Britain, and-somewhat surprisingly - on Italy, as well as on the West German states. Its estimate of the value of the foreign country and West German studies for the First Report itself is summed up in one sentence:

With respect to some aspects of the problem studied, the assumption has been confirmed that there are in foreign countries, but also in the West German States, methods, techniques and beginnings of organizational forms for an improvement of the political decision process which deserve special attention in continued work on government and administrative reform.

This will have to be read in conjunction with an earlier characterization of reports on the West German states as "in part, very instructive"100 - an evaluation that is not repeated in the passage just quoted.

\section{Conclusion}

The first two sections of the present paper seek to summarize the main features of the First Report of the West German Project Group for Government and Administrative Reform, and to outline the impact of that report on government reorganization in West Germany. Although it is hoped that they will be of interest to students of government organization in other countries merely by virtue of the subject matter chosen, they are, at base, secondhand descriptions by a relative outsider in another language-the dreary standard fare of what used to be so euphemistically called "Comparative Government."101

\footnotetext{
${ }^{80}$ Id. at 265 .

${ }^{97} I d$. at 267 .

${ }^{98}$ Id. at 27I-73. The "Hamburg Triangle" consists of the Planning Staff of the City-State Council Offce (Senatskanzlei), the central Organization Authority, and the Finance Department. For details, see 2 id. at $287-88$.

${ }^{90} 2$ FIRST REPORT 267-3r3; see the Project Group's introduction to that volume, id. at v, vi.

100 Id. at vi.

${ }^{101}$ Von Beyme, Möglichkeiten und Grenzen der vergleichenden Regiertngslehre, 7 Pouırısche VienTELYAFRSSCFRIFT 63, 78 n.36 ( 1966 ), notes "drops in information levels at linguistic and political frontiers," and observes, with refreshing candor: "A book is seldom found worth translating into
} 
The third section, on the other hand, pursues somewhat more ambitious aims. It seeks to render a reasonably comprehensive account of those portions of the Report and of the author's country study on the United States which might be of significance in assaying the practical value of foreign country studies in connection with government reorganization or, more generally, the analytical utility of comparative public law.

The conclusion will have to be that assaying itself. It will rest on three criteria, first alone and ultimately in combination: (I) the utility of foreign country studies for West German government reorganization planning; (2) the significance of the West German experience for the United States; and (3) the value of studies such as the ones here discussed for insights into the nature and the workings of political institutions generally.

The utility of the foreign studies for West German government reorganization planning seems directly proportional to the distance of their findings from the distinguishing characteristics of the respective foreign political systems described. There is more interest in methods than in institutions, and more interest in techniques than in methods. This might be another way of saying that while political planning and decision-making may in time become a truly international discipline in the same manner as the rather obvious precursor, business management, ${ }^{102}$ the study of political institutions is not likely to achieve the same degree of cosmopolitanism. Political institutions do differ from country to country; and apples are better compared with other apples than with oranges. ${ }^{103}$ This explains the marked preference of the Project Group for the West German state studies over the foreign country studies.

For the United States, there are, in the nature of things, only some incidental insights. The current academic neglect of organizational constitutional law seems shocking and inexcusable, even though flexibility in this area is likely to be an asset rather than a liability. Flexible rules are quite capable of study. On a more mundane level, it is hoped that the partisans and critics of PPBS will not ignore the gauntlet of the challenger from overseas. ${ }^{104}$ PPBS discussion, which has been quite parochial, might well profit from an infusion of foreign ideas, based on experience

the language of the country investigated." A notable recent exception would be G. LoewenBerg, Paritament in the German Political System (I966), which is generally acknowledged to be by far the best work on the Bundestag, and has indeed appeared in German translation: G. LoEwENBERG, Parlanientarismus im poltrischen System der Bundesrepublix Deutschland (r969). See also Scharpf, Judicial Review and the Political Question: A Functional Analysis, 57 YaLE L.J. 5I7 (rg66), which is a condensation of his study, Grenzen ruchterLicher Verantwortung. Die polttical cuesTTON-DOKIRIN IN DER ReChtsPRechung Des SUPREMAE Court (1965); and Ehmke, supra note 7.

${ }^{102}$ The causes for that development become apparent from a reading of Vagts, The Maltinational Enterprise: A New Challenge for Transnational Law, 83 HARv. L. Rev. 739 (1970).

${ }^{103}$ Acknowledgment is due to Hardin, An American Lawyer Looks at Civil Jury Trial in Scotland, III U. PA. L. REv. 739 (1963).

${ }^{104}$ See pp. 64r, 660 supra. Certainly the charge of parochialism cannot be levelled against German authors on intermediate-term fiscal planning. See especially Mennel, supra note 89. 
with West German intermediate-term budget planning. A third insight would appear to be that in view of the significance attributed by the Project Group to the West German state studies, there might be some utility in similar within-country comparative studies in the United States. On this score, more of the fault (if any) would seem to lie with the cosmopolitan preoccupations of the comparativists than with the parochialism of students of public administration; and both appear to be already in the process of mending their ways. ${ }^{105}$

Finally, there is the question as to the utility of comparative studies for a better understanding of political institutions generally. Because of its limited mandate which excluded recommendations requiring constitutional amendments for their implementation, the Project Group felt little temptation to engage in speculation on this august level. There might also have been some unexpressed preference for the West German form of government-surely not an entirely misplaced sentiment in the light of the speedy implementation of the major recommendations of the First Report.

In is difficult to approach the subject here treated without being drawn into emotionally charged discussions about the relative merits of the presidential and parliamentary forms of government. ${ }^{106}$ Perhaps, however, we can still utilize some insights of this study in order to clarify the ultimate issues.

A chief realization for the present author was that at least as regards the (presently crucial) central executive and legislative institutions, there is less difference between the British constitution and Continental constitutionalism than there is between the British and the United States systems of government. The British model appeared to us as much more rational and appealing; constitutional life in the United States seemed persistently bedeviled by essentially personal power conflicts and an undercurrent of disregard for the public character of public office.

This appraisal coincided to a remarkable extent with the trenchant critiques of a noted British political journalist in Washington. ${ }^{107}$ However, somehow two key pieces of the puzzle seemed to be missing. Did the United States really combine

\footnotetext{
${ }^{105}$ Much of creative American research into state and local government and into political bchavior at these levels has been at least intuitively comparative in nature; see, e.g., KALIENBAcH, supra note $7 \mathrm{I}$. Recent studies tend to be more explicit as to the method employed; e.g., Chaffey, The Institutionalization of State Legislatures, A Comparative Study, 23 Western PoL. Q. I80 (1970). H. JACOB \& K. VINEs, Polmtics in the American States, A Comparative ANalysis (1965), although primarily a teaching tool, might have heralded the beginning of a new era.

${ }^{106}$ BrownLow, supra note 3 , at 356 , notes "the curious notion, especially widespread among political scientists, that the American government would be better if the presidential system were abandoned and the parliamentary system adopted or at least if every step short of the utter subversion of the constitutional separation of powers were undertaken that would bring us nearer to the better British model." C. Friedrich, The Impact of American Constitutionalisar Abrond r7-39 (I967) would appear to be quite immune against this "curious notion"-although not, perhaps, against some others. See Ryan, Book Review, 47 Can. B. Rev. 330 (I969). For the classic debate on this issue, sce Price, The Parliamentary and Presidential Systems, 3 Pub. AD. Rev. 317 (I943); Laski, The Parliamentary and Presidential Systems, 4 Pus. AD. Rev. 347 (I944); and Price, A Response to Mr. Laski, id. at 360.

${ }^{103}$ Fairlie, Help from the Outside, in The Presidentiar Abvisory System I44 (T. Cronin \& S. Greenberg eds. 1969); Fairlie, Thoughts on the Presidency, The Publuc INTERest, Autumn, 1967, at 28 (I967).
} 
"the world's most modern society with one of the world's most antique polities"? 108 If so, is such a society really compatible with a modern polity?

The first piece has fallen into place by a belated reading of Professor Samuel Huntington's seminal study from which the quotation is taken. As he convincingly demonstrates, the United States political system is essentially an English export, but of Tudor vintage. Even "nineteenth-century Europeans had every reason to be fascinated by America: It united a liberal society which they were yet to experience with a conservative politics which they had long since forgotten."109

Rather obviously, such a system is not readily exported in turn. However, we are still looking for the second piece missing from the puzzle, which has now assumed more definite but also more forbidding shape. Is the political system of the United States a beneficial, a detrimental, or, perhaps, simply an indifferent factor in the quest for a modern society? At least one perceptive observer would embrace the first of these alternatives; ${ }^{110}$ there are, no doubt, others-now possibly including Professor Huntington ${ }^{111}$-who will espouse different views. The student of public administration and of comparative government can leave this ultimate question open once he has realized its existence. By concentrating on the more down-to-earth problems of improvements in political planning methods and techniques, it is hopefully concluded, he can seek to achieve insights that are useful and politically acceptable both to advanced societies and to developed polities.

\footnotetext{
${ }^{108}$ Huntington, Political Modernization: America v. Europe, I8 WorLd Pourtics 378, 406 (I966), in S. Huntington, Political Order in Changing Soctemes i29 (ig68).

200 Huntington, supra note 108, at 133. Professor Huntington's thesis is accepted by Long, Reflections on Presidential Power, 29 PuB. Av. REv. 442, 443-44 ( $\mathrm{Ig69}$ ), but rejected by LaPalombara, Book Review (of Huntington), 78 YAIE L.J. I253, x269-70 (I969).

${ }_{110}$ D. Price, The Scientific Estate (1965). See also Huntington, supra note 108, at 132: "The American experience demonstrates conclusively that some institutions and some aspects of a society may become highly modern while other institutions and other aspects retain much of their traditional form and substance. Indeed, this may be a natural state of affairs. In any system some sort of equilibrium or balance must be maintained between change and continuity. Change in some spheres renders unnecessary or impossible change in others. In America the continuity and stability of governmental institutions has permitted the rapid change of society, and the rapid change in society has encouraged continuity and stability in government. The relation between polity and society may well be dialectical rather than complementary."

${ }^{111}$ Professor Huntington's r 968 monograph qualifies his views as set forth above with the followlowing statement:

"These conservative institutions could well change more rapidly in the future than they did in the past. External security and internal consensus have been the principal factors militating against the modernization of American political institutions. The former disappeared in the early twentieth century; the latter appears at times to be on the verge of disruption. The political institutions suited to a society which did not have to worry about external dangers may be inappropriate for one continually involved in a balance of terror, cold war, and military interventions in distant portions of the globe. So also, the problems of race relations and poverty strengthen demands for action by the national government. The needs of national defense and social reform could undermine the traditional pluralism inherited from the past and hasten the centralization of authority and structural differentiation in American political institutions." Huntington, stpra note 108, at 133. So far as can be determined, this is the only variant from the 1966 text that is not generally supportive of the views therein expressed.
} 


\section{An Index to Modern Legal Problems}

One each of the following topics, LAW AND CoNTEnTPORARY Problems has published or will publish a symposium dealing with the legal, economic, administra. tive, and other social-science aspects of the subject. The date indicates the year of publication.

\begin{tabular}{|c|c|c|c|}
\hline Academic Freedom & 1963 & Health Caref & 1970 \\
\hline Administrative Regulation & 1961 & Hemispheric Trade & 1941 \\
\hline African Law & 1962 & Home Financing & 1938 \\
\hline Agricultural Adjustment in the South & 1934 & Housing & 1947 \\
\hline Air Cargo & 1950 & Housing: Perspectives and Problems & 1067 \\
\hline Air Pollution Control & 1968 & Housing: The Federal Role & 1967 \\
\hline Alcoholic Beverage Control & 1940 & Immigration & 1956 \\
\hline Alimony & 1939 & Instalment Selling & 1935 \\
\hline Antipoverty Programs & 1966 & Institutional Investments & 1952 \\
\hline Antitrust Laws and Single-Firm & & Institutionalized Presidency, The & 1970 \\
\hline Conduct & 1965 & International Commodity Agreements & 1963 \\
\hline Atomic Power Development & 1956 & International Control of Propaganda & 1866 \\
\hline Aviation Transport & 1946 & International Human Rightst & 1040 \\
\hline Bankingt & 1967 & International Trade Barriers & 1946 \\
\hline Children of Divorced Parents & 1944 & Interterritorial Freight Rates & 1047 \\
\hline Close Corporation & 1953 & Investment of Trust Funds & 1938 \\
\hline Collection of Real Property Taxes & 1936 & Judicial Ethics & 1070 \\
\hline Collective Bargaining Under the & & Jurimetries & 1963 \\
\hline Wagner Act & 1938 & Labor Dispute Settlement & 1947 \\
\hline Combating the Loan Shark & 1941 & Labor in Wartime & 1942 \\
\hline Commercial Arbitrationt & 1952 & Land Planning in a Democracy & 10 \\
\hline Commercial Codet & 1951 & Legislative Reapportionment & 195 \\
\hline Communicationst & 1969 & Literary and Artistic Products and & \\
\hline Consumer Gredit Reform & 1968 & Copyright Problems & 195 \\
\hline Consumption Taxes & 1941 & Loan Shark Proble & \\
\hline Cooperatives & 1948 & Low-Cost Housing and Slum Clearanco & 103 \\
\hline Correction of Youthful Offenders & 1942 & Medical Care & 1939 \\
\hline Crime and Correction & 1958 & Medical Progress and & 196 \\
\hline Delivered Pricing & 1950 & Middle East Crisis: Test of & \\
\hline Divorce: A Re-Examination of & & International Law & 100 \\
\hline Basic Concepts & 1953 & Migratory Divorce & 193 \\
\hline Electoral Processt & 1962 & Narcotics & 1957 \\
\hline Emergency Price Control Act & 1942 & Nationalization of British Industries & 1051 \\
\hline Enemy Property & 1945 & New Look in Corporation Law & 195 \\
\hline European Regional Communities & 1961 & New Trends in the Conflict of Laws & 1963 \\
\hline Excess Profits Taxation & 1943 & Obscenity and the Arts & 195 \\
\hline Expert Testimony & 1935 & Old Age Security and Welfare Titles & \\
\hline Farm Tenancy Legislation & 1937 & of the Social Security Act & 108 \\
\hline Federal Courts & 1948 & Patent Systemt & 194 \\
\hline Federal Employers' Liability Actt & 1953 & Population Control & 190 \\
\hline Federal Income and Estate Taxation & 1940 & Presidential Office & 195 \\
\hline Federal Powers Over Crime & 1934 & Preventive Law of Conflicts & 195 \\
\hline Financial Protection for the Motor & & Price Control in a Cold Wa & \\
\hline Accident Victim & 1936 & Price Discrimination and & \\
\hline Financing Small Business & 1945 & Price Cutting & 193 \\
\hline Food, Drug, and Cosmetic Legislation & 1939 & Privacy & 196 \\
\hline Government Marketing Barriers & 1941 & Private Insurance & 1950 \\
\hline Government Contractsł & 1964 & Problems of the Aging & 190 \\
\hline Government Tort Liability & 1942 & Protection for the & \\
\hline † Published in & & Canaman & \\
\hline
\end{tabular}

